\title{
Guerra biológica, guerra química y bioterrorismo
}

Gema Sánchez Medero*

\subsection{Introducción}

Es en el siglo XXI en el que el bioterrorismo es una de la más terribles amenazas, ya que a finales del siglo XX y comienzos de este siglo, se han conseguido los mayores avances en ingeniería genética, ya que alterar los genes de agentes infecciosos para conferirles capacidades mortíferas se ha convertido, según algunos expertos en genética molecular, en algo fácilmente accesible y realizable por personas con la formación adecuada. Solo bastaría con extraer una porción de ADN de una bacteria que contenga el gen que codifique la característica buscada, por ejemplo, una gran potencia infectiva, copiarlo e introducirlo en el genoma de otra que sea letal. Aunque desde el punto de vista práctico, solo un pequeño número de microorganismos tienen la potencialidad de utilizarse efectivamente como armas biológicas. Hay que tener en cuenta que el microorganismo elegido se puede cultivar en grandes cantidades y dispersar con facilidad (preferiblemente como aerosol); debe ser muy contagioso y fácil de expandirse de persona a persona; que con bajas dosis del organismo elegido se pueda iniciar la enfermedad, ya que muchas

* Profesora de Ciencias Políticas y de la Adminstración de la Universidad Complutense de Madrid. 
veces no basta para ese propósito que un solo virus o una bacteria infecte a una persona (Diomedi, 2003).

No obstante, este tipo de guerra no es nuevo, y de hecho se ha usado en múltiples ocasiones desde la antigüedad. Los asirios, por ejemplo, envenenaron los pozos de agua del enemigo con ergotamina, producida por el cornezuelo del centeno. Los romanos arrojaban, por ejemplo, animales muertos en los suministros de agua de sus enemigos con el objetivo de contaminarlos o matarlos. Método que también siguieron los persas y los griegos. Los tártaros, en el siglo XIV, lanzaron con catapultas cadáveres infectados por peste sobre las murallas de la ciudad de Kaffa, esperando así contagiar a los habitantes. En 1710, las tropas rusas usaron, supuestamente, la misma técnica, es decir, con sus cadáveres infectados de peste trataron de contagiar a las tropas suecas. La utilización del virus de la viruela como arma biológica fue empleada por primera vez por el Ejército británico en contra de los nativos norteamericanos entre 1754-1767, cuando el general Jeffrey Amhest ordenó la entrega de mantas que habían sido utilizadas por los enfermos de viruela entre nativos norteamericanos que militaban con los franceses, matando hasta el 50\% de las tribus afectadas. Pero con el descubrimiento de la vacuna contra la viruela por Edward Jenner y el siguiente desarrollo de la vacunación, la amenaza potencial de utilizar la viruela como arma biológica disminuyó considerablemente. En 1797, Napoleón, en su campaña de Italia, parece que intentó contagiar de paludismo a los habitantes de Mantua.

También existen evidencias de que el Ejército alemán desarrolló, durante la Primera Guerra Mundial, un programa para la creación de armas biológicas. En todo caso, los bacilos Bacillus anthracis y Burkholderia mallei fueron usados por los alemanes para contaminar el ganado vacuno que fue exportado a Rusia. Durante la Segunda Guerra Mundial los prisioneros en campos de concentración nazis fueron expuestos a Ricketsia prowazekii, al virus de la hepatitis A y Plasmodium sp, con el objetivo de crear sulfonamidas y vacunas contra estas infecciones. Sin embargo, no existe evidencia alguna de que estos experimentos fueron llevados a cabo para la creación de armas biológicas por parte del Ejército nazi. Aunque no fueron los únicos, ya que los ingleses también planificaron ataques con 500 bombas de racimo, cada una de las cuales contenía 106 bombas 
de ántrax, que podrían haber matado al 50\% de los habitantes de las seis ciudades alemanas. Además se sospecha que los rusos utilizaron la tularemia contra los alemanes durante el sitio de Stalingrado, esta enfermedad es producida por la bacteria Francisella tularensis y, usualmente, se trasmite a través de picaduras de garrapatas, pero también se puede adquirir por beber agua contaminada o por estar en contacto con carne de mamíferos infectados (Diomedi, 2003). En esta misma guerra, los japoneses hicieron uso de armamento biológico contra los chinos, además de experimentar con este en prisioneros estadounidenses.

Asimismo, en países como Canadá, la Unión Soviética, el Reino Unido y los Estados Unidos, los programas de armamento biológico se expandieron al finalizar la guerra y cobraron auge durante la Guerra Fría. Y a pesar de que el aumento de estos programas se detuvo, al menos oficialmente, con la firma del Tratado surgido de la Convención de Armas Tóxicas y Biológicas de 1972, algunos países continúan teniendo programas de desarrollo de armamento biológico. Pese a que en el citado tratado se prohíbe el uso y desarrollo de armas biológicas, y fuera suscrito por 140 naciones. Aun así, se sospecha que China, Vietnam, Laos, India, Bulgaria, Irak, Irán, Taiwán, Siria, Cuba, Corea del Norte, Egipto, Israel, Japón, Estados Unidos y algunos países del ex bloque soviético todavía tienen programas de desarrollo de armamento biológico, e incluso, algunos de ellos cuentan con grandes cantidades almacenadas (Diomedi, 2003).

El uso a gran escala de productos químicos tóxicos como armas químicas se produjo a partir de la Primera Guerra Mundial, gracias, en parte, al crecimiento de la industria química. Más de 110.000 toneladas fueron diseminadas sobre los campos de batalla, la mayor parte en el frente occidental. Inicialmente, los productos químicos se usaron, no para causar víctimas en el sentido de poner combatientes fuera de acción, sino más bien para hostigarlos. Aunque los irritantes sensoriales utilizados eran lo suficientemente poderosos para incapacitar a quienes eran expuestos a ellos, se emplearon, principalmente, para expulsar a los combatientes enemigos de las trincheras o de otros refugios que los protegieran del fuego convencional, o para alterar la artillería enemiga o los suministros. 
Si bien con el tiempo se recurrieron a ellos para causar la muerte. En este sentido, mencionar que el cloro fue el primer producto químico letal utilizado en la Gran Guerra, pero el desarrollo más significativo de agentes letales se produjo durante la Segunda Guerra Mundial, cuando Alemania manufacturó el tabún, el primero de lo que se ha denominado "agentes G" de los gases nerviosos. Una planta piloto para producir tabún estaba en pleno funcionamiento cuando empezó la guerra en septiembre de 1939. El trabajo con los agentes G continuó en varios países después de la guerra. Así, durante la Guerra del Golfo de 1981-1988, los investigadores de las Naciones Unidas recolectaron evidencias sobre la utilización de unos agentes de la serie, como el VX y el VR, más tóxicos que los de agente G. Por tanto, lejos de acabar con este tipo de armamento, se ha ido perfeccionado, hasta el punto de hacerle cada vez más letal, tal es así que, por ejemplo, con un gramo de toxina botulínica pura se puede matar a 10 millones de personas. De ahí, que sea necesario adentrarse en el estudio de la guerra biológica y la guerra química.

\subsection{Los conceptos de "guerra biológica", "guerra química" y "bioterrorismo"}

La guerra biológica o bacteriológica es una forma de combate, en el cual se emplean armas de diferentes tipos que contienen virus o bacterias capaces de infligir daño masivo sobre sus fuerzas militares y civiles. Otra definición, es la que considera la guerra biológica como el uso intencional de organismos vivos o sus productos tóxicos para causar muerte, invalidez o lesiones en el hombre, animales y plantas ${ }^{1}$. Así, los agentes químicos de guerra son desarrollados por el hombre y pueden ser dispersados en forma de gas, vapor, líquido, aerosol, o polvo fino. El bioterrorismo es el término utilizado para definir el empleo ilegítimo de microorganismos patógenos, toxinas o sustancias dañinas contra la población con el propósito de generar enfermedad o muerte, y así intimidar a gobiernos o sociedades, y alcanzar sus objetivos ideológicos,

1. Del folleto "Efectos de los Agentes de la Guerra Biológica", publicado por el Departamento de Salud, Educación y Bienestar de los Estados Unidos de Norteamérica, en julio de 1959. 
religiosos o políticos (Soteras, 2008b). O como nos indica el Centro para el Control y la Prevención de Enfermedades (CDC) de los EE.UU., el bioterrorismo es la liberación de bacterias, virus o toxinas con el propósito de causar daños o matar a personal civil (García de los Ríos y Jiménez, 2007, p. 6). Así, como se puede comprobar la diferencia entre guerra biológica y bioterrorismo se encuentra en los destinatarios de los daños, en la guerra biológica es el enemigo, mientras que en el bioterrorismo es el personal civil; el objetivo en los ejércitos es buscar la victoria militar, mientras que en un grupo terrorista lo que pretende es alcanzar notoriedad y provocar terror en la población civil del enemigo.

\subsection{La guerra "biológica" y "química": Los programas de los Estados}

El uso de armas biológicas y químicas proporciona a los Estados, los terroristas y grupos insurgentes una serie de ventajas que no siempre se encuentran en otro tipo de herramientas. En primer lugar, un ataque biológico o químico puede ocurrir sin dar ningún aviso, ya que este tipo de agentes pueden ser diseminados, mediante sistemas de armamentos que no llaman la atención en un área alejada del objetivo, el aire ya se encargará de hacerlo llegar. Además este tipo de agentes no pueden ser detectados por los sentidos, para ello es necesario contar con una serie de instrumentos adecuados, por no hablar del tiempo que hay que invertir para detectarlos. En segundo lugar, un ataque biológico o químico puede penetrar prácticamente en cualquier parte. En tercer lugar, un ataque biológico o químico puede producirse sin destruir físicamente ninguna estructura enemiga, cosa que es básica, porque después podría ser necesario utilizarla. En cuarto lugar, los ataques biológicos y químicos pueden ocasionar grandes pérdidas con dosis relativamente bajas, etc.

De ahí, que sean muchos los países que en un momento u otro han desarrollado programas de armas biológicas o químicas, solo por hacer referencia a algunos: la Unión de Repúblicas Soviéticas (URSS), los Estados Unidos, Reino Unido o Francia. 


\subsubsection{La Unión de Repúblicas Soviéticas (URSS)}

La URSS mantuvo distintos laboratorios encargados de desarrollar sustancias químicas y biológicas para que los servicios secretos las utilizasen para llevar a cabo algunos asesinatos. Las actividades de estos laboratorios perduraron desde los años 20 hasta los años 70, aproximadamente. Así, en 1921 se creó el primer laboratorio, denominado "Oficina Especial", a cuyo cargo estuvo el profesor Ignatti Kazakov (Birstein, 2001). Uno de los principales responsables en el desarrollo de estas sustancias fue el doctor Grigory Mairanovsky, bioquímico moscovita, jefe del "Laboratorio 1" desde 1939 hasta finales de los años cuarenta (Pita, 2008, p. 417). En este laboratorio se llevaron a cabo importantes estudios sobre la ricina, que incluían experimentos con prisioneros condenados a muerte, para analizar sus reacciones y comportamientos (Pita, 2008, p. 417).

Desde que la Unión Soviética firmará el Convenio de Armas Biológicas, el 10 de abril de 1972, el programa de armas biológicas sería ejecutado principalmente por la agencia civil Biopreparat, aunque también participaban el Ministerio Soviético de Defensa, el Ministerio de Agricultura, el Ministerio de Industria Química, el Ministerio de Salud y la Academia de las Ciencias de Rusia. Las armas fueron desarrolladas en laboratorios en zonas aisladas de la Unión Soviética, incluyendo instalaciones de movilización en Omutininsk, Penza y Pokro e instalaciones de investigación en Moscú, Strizhi y Vladímir. Estas fueron probadas en varios centros en la isla Vozrozhdeniya en el Mar de Aral, disparando las armas al aire por encima de monos atados a postes, luego estos serían objeto de seguimiento para determinar sus efectos. En total se calcula que hubo 18 laboratorios y centros de producción, y los patógenos más usados por este programa fueron: la viruela, el carbunco, la encefalitis esquina venezolana, la tularemia, la gripe, la brucelosisi, el marbug, el ébola, el virus junin, la fiebre $Q$, el virus machupo, y el veepox. De tal manera, que se cree que la URSS creo millones de toneladas de estos agentes para la supuesta guerra biológica. En todo caso, este programa concluyó en 1992, pero eso no significa que Rusia haya dejado de realizar actividades que están prohibidas por la Convención sobre Armas Biológicas. Es más, Rusia firmó la Convención sobre Armas Químicas, 
el 13 de enero de 1993, y sin embargo, cuenta con más de tres plantas de destrucción de armas químicas, en Gorny, Kambarka y Maradykovsky, y está planificado la construcción de otras cuatro.

\subsubsection{Los Estados Unidos de América}

El programa estadounidense de armas biológicas comenzó oficialmente bajo el gobierno del presidente Franklin Roosvelt en 1943. Durante la Segunda Guerra Mundial la investigación y desarrollo de armas biológicas se concentró en el Fuerte Detrick, en Maryland, para que fueran producidas en un complejo industrial cercano, llamado "Terre Haute" (Indiana), que se dedicó a la producción de esporas de ántrax y la fabricación de bombas con dicha sustancia. Pero al terminar la guerra, esta planta fue reconvertida en laboratorio para fabricar antibióticos, aunque posteriormente fue reemplazada por un nuevo complejo de producción de armas biológicas, el Pine Bluff Arsenal, ubicado en Arkansas. Este nuevo laboratorio inició su actividad en 1954 y, supuestamente, operó hasta la declaración de Nixon ante el Comité del Senado, en 1969, en la que aseguraba el retiro de EE.UU. de la investigación, desarrollo y producción de armas químicas y biológicas. Pero estas declaraciones hicieron público que la CIA conservaba todavía 11,405g de saxitoxína y $8 \mathrm{mg}$ de veneno de cobra. Además de las toxinas prohibidas, también almacenaba en 1975 pistolas para dardos tranquilizantes y distintos agentes químicos, entre los que destacaban BZ, halotano, hioscina, fenciclidina y pastillas de cianuro.

Así que, aunque EE.UU. renunció a su programa en 1969 y, posteriormente, ratificó la Convención para la Prohibición de Armas Biológicas y Toxinas, tres periodistas en el 2001 describían en su libro Germs tres programas del Gobierno estadounidense (el Clear Vision, el Bacus y la Agencia de Inteligencia de Defensa), iniciados a finales de los años noventa, que resultaban polémicos al rayar la línea entre un programa defensivo y ofensivo con armas biológicas, lo que podría suponer la violación de la Convención (Pita, 2011). En el programa Clear Vision, la Agencia Central de Inteligencia construyó y probó un modelo de una bomba para esparcir gérmenes, y para ello crearon una fábrica de gérmenes que fueran más letales que el ántrax en el desierto de $\mathrm{Ne}$ - 
vada. Allí, además, se almacenaron dichas armas biológicas en formas de bombas. El proyecto BACUS, cuyo objetivo era intentar construir, sin ser detectados por las agencias de inteligencia, una pequeña planta de producción de esporas de Bacillus thuringiensis, cuyos materiales deberían obtenerse de empresas comerciales (Pita, 2011, p. 101). El programa dirigido por la Defense Threat Reduction Agency (DTRA) se llevó a cabo entre 1999 y 2000, periodo en el cual construyó la instalación y se produjeron dos libros de B. thuringiensis (Pita, 2011, p. 101). En el 2001, la Agencia de Inteligencia de Defensa (DIA) contrató al Battelle Memorial Instittute para que obtuviese una cepa de $B$. anthracis resistente a la vacuna del carbunco (Pita, 2011, p. 102).

Además, recientemente se ha descubierto a este respecto que EE.UU., con la aprobación del Gobierno, llevó a cabo secretamente experimentos en Guatemala entre 1946 y 1948, en los que se utilizaron enfermos mentales y prostitutas, en total se emplearon a 5500 individuos como conejillos de indias, los cuales fueron divididos en dos grupos, los que fueron sometidos a estudios de diagnóstico y los que recibieron inoculación intencionada con los patógenos. Así, unas 1300 personas fueron expuestas a enfermedades venéreas, mediante contacto directo o inoculación. De ellas, 700 recibieron algún tratamiento (ABC, 31/08/2011). El principal objetivo de la inoculación con la gonorrea era probar la eficacia de una variedad de medidas profilácticas, entre ellas varias lociones químicas, así como la de penicilina oral. Dicho programa duró 75 años y fue financiación por el Instituto Nacional de Salud.

Aunque no ha sido el único caso, ya que entre 1954 y 1973, EE.UU. se preparaba para un ataque bacteriológico durante la Guerra Fría. Así, durante la operación "Whitecoat", lograron convencer a 2300 objetores de conciencia para los experimentados (ABC, 31/08/2011). No hubo muertos, pero se les sometió a radiación, químico y agentes infecciosos muy peligrosos. Igualmente, entre 1932 y 1972, los servicios de salud de EE.UU. estudiaron la progresión natural de la sífilis si no era tratada, en 339 afroamericanos, quienes no fueron informados ni dieron su consentimiento para tal prueba. El resultado fue 28 muertos y otros 100 enfermos con complicaciones médicas relacionadas. Asimismo, durante décadas los EE.UU. han probado gas mostaza, VX, sarín, cianuro de 
hidrógeno y otros agentes neurotóxicos. En los primeros experimentos, se aplicó las sustancias de forma directa a los soldados destinados en Panamá.

\subsubsection{El Reino Unido}

Finalizada la Segunda Guerra Mundial, la Comisión de Guerra Biológica británica fue sustituida por la Subcomisión Interservicios de Guerra Biológica, que en abril de 1947 pasó a ser la Subcomisión de Guerra Biológica de los Jefes de Estado Mayor (Pita, 2011, p. 83). El programa ofensivo continuaría en el Departamento de Defensa Microbiológica de Porton Down, a cargo de David Henderson, y la política de uso de estas armas por parte del Gobierno británico se describía como "ofensa para la defensa", dejando claro que el Protocolo de Ginebra era un tratado de la "no primer uso" pero que no prohibía la investigación, desarrollo y producción de armas biológicas (Pita, 2011, p. 84). También se sabe que, entre 1953 y 1954, los servicios de inteligencia británicos realizaron experimentos con marineros y soldados, en muchos casos sin su consentimiento, para probar sustancias químicas que pudiesen utilizarse como "drogas de la verdad" en interrogatorios (Evans, 2005). Hasta tal punto debió llegar la cosa que el M16 se comprometió a dar compensaciones económicas a estas "cobayas" humanas (Pita, 2008, p. 419). Hoy en día se encuentra cumpliendo con el compromiso de eliminar el armamento biológico y químico en virtud del Convenio Internacional sobre Prohibición de Armas Químicas suscrito en abril de 2008.

\subsubsection{Francia}

No se sabe mucho del programa ofensivo francés, la poca información disponible fue publicada por el investigador Oliver Lepick en el 2006. El programa tuvo dos fases, una primera entre 1947 y 1956, en la que hubo un importante programa de investigación y desarrollo, y una segunda etapa hasta 1972, en la que se produjo un gran recorte de presupuesto debido a la prioridad que se le dio al programa nuclear (Lepick, 2006). Además, en 1952 se creó la Comisión de Estudios y Experimentaciones Químicas y Bacteriológicas del Ejército de Tierra con el fin de coordinar las actividades relacionadas con armas biológicas y químicas 
(Pita, 2011, p. 106). Pero en 1964, el Consejo de Defensa decidió que las actividades del programa biológico y químico eran secundarias con respecto al programa nuclear, y quedaban limitadas a aquellas relacionadas con aspectos defensivos. El Centro de Estudios de Le Bouchet llevaría a cabo algunos estudios de diseminación de toxina botulínica hasta 1969 y, finalmente, entre 1972 y 1973, el programa se dio por finalizado oficialmente (Leitenberg, 2004, p. 56).

\subsection{El bioterrorismo}

Los atentados del 11-S de 2001 fueron los desencadenantes para que se comenzarán a hablar de un posible atentado terrorista con armas de destrucción masiva. Las sospechas de esta posibilidad se basarían en las características de las nuevas formas de terrorismo (García de los Ríos y Jiménez-Gómez, 2007, p. 7). Los grupos terroristas actuales no parece que estén sometidos a ninguna disciplina vertical próxima, sino a una red dispersa y con unas directrices muy generales (García de los Ríos y Jiménez-Gómez, 2007, p. 7). Normalmente las distintas células no están activas en todo momento, es más, suelen hacerlo después de llevar años realizando una vida totalmente normal. Son comandos que están desconectados uno de los otros, y solo en un momento determinado se les encomienda una misión, para lo cual tienen total libertad de acción. Pero además hay que tener en consideración otro hecho, la desintegración de la Unión Soviética está sirviendo de abastecimiento armamentístico a todo este tipo de grupos terroristas o insurgentes.

Además, el uso de armas químicas y biológicas ofrece muchas ventajas a los terroristas, como la capacidad limitada para descubrir estas armas por parte de los organismos internacionales, el costo relativamente bajo para desarrollarlas, su imagen aterradora y el impacto psicológico en la población. Por tanto, existen diversos motivos para que los terroristas usen este tipo de armas. Por ejemplo, son una poderosa herramienta psicológica para instigar al desorden, ya que las enfermedades que pueden causar este tipo de agentes pueden provocar pánico, interrupción en las actividades y muertes masivas. Además, como normalmente, el tiempo de incubación de estas enfermedades no suele ser inmediato, les facilita el escape y la ocultación. Estos agentes pueden adquirirse en una 
fuente ilegal, o bien legalmente al comprarlos como químicos industriales, o ser producidos en laboratorios caseros.

Así, si los grupos terroristas no han empleado más esta herramienta en sus atentados terroristas es porque un ataque de este tipo requiere franquear una serie de importantes obstáculos técnicos, como son: la obtención de ingredientes especializados de armas químicas o de cepas microbianas, la adquisición del equipo y de los conocimientos necesarios para la producción y dispersión de los agentes, y la creación de una estructura organizativa capaz de resistir la infiltración o detección temprana por los organismos policíacos.

\subsubsection{Secta Aum Shinrikyo}

Hasta los atentados de la secta Aum Shinrikyo con gas sarín en Japón en 1994 y 1995, la utilización de las armas químicas había quedado relegada, prácticamente, al ámbito militar. El 27 de junio de 1994 miembros de dicha secta llevaron un camión refrigerador, transformado en un sistema para liberar una nube de gas sarín, cerca de donde residían tres jueces, en la ciudad Matsumoto, que iban a dictar sentencias desfavorables por unos terrenos que había adquirido la organización de forma ilícita. Se utilizó un sistema improvisado para la diseminación de sarín, que consistía en un sistema de calentador, ventilador y goteo; el vapor de sarín se dispersó desde la ventana de una camioneta de reparto camuflada. El camión se estacionó en el aparcamiento de un supermercado, al lado de una zona ajardinada, que estaba a unos 37 metros del edificio donde vivían los tres jueces (Pita, 2008, p. 446). El atentado consiguió parte de su objetivo, ya que los jueces resultaron afectados, retrasando el dictamen de la sentencia, pero además hubo 7 personas muertas y centenares de afectados (Pita, 2008).

El otro atentado se produjo el 20 de marzo de 1995, en el metro de Tokio en plena hora punta. El mismo se llevó a cabo depositando el gas en cinco trenes, en paquetes de plástico en el suelo que fueron pinchados con paraguas afilados para liberar el gas. El objetivo era provocar el mayor número posible de muertes, ya que las profecías de su religión así lo vaticinaban. El resultado final fue que 12 personas murieron, y entre 
5000 y 6000 sufrieron las consecuencias de las intoxicaciones producidas por el mencionado gas. El balance de víctimas hubiera sido mayor si el gas hubiera sido de mayor calidad. Como consecuencia de los atentados la organización fue descabezada. Muchas de sus sedes fueron desmanteladas, y se encontraron con el rechazo absoluto por parte de la población japonesa. Fueron procesados por la ley anti-subversiva, aunque finalmente la organización no fue prohibida. Durante los juicios, 12 miembros de la secta fueron condenados a muerte, pero hasta la fecha aún no se ha ejecutado a ninguno. Shōkō Asahara fue sentenciado a muerte en la horca el 27 de febrero de 2004, actualmente continúa esperando su ejecución por el asesinato de 27 personas, incluyendo los fallecidos en el atentado del metro.

Se sabe que esta secta intentó en 1990 rociar la toxina botulínica por las inmediaciones del parlamento y el centro de Tokio. En 1993 liberaron en las cercanías del Palacio Real esta misma toxina, y unos días después esparcieron esporas de carbunco desde la azotea de un edificio de ocho plantas del este de Tokio. Aunque ninguno de estos ataques registraron heridos ni muertos.

Para poder llevar a cabo este tipo de atentados, este grupo terrorista poseía una finca en Kamakuishki, con varios edificios, tanto de producción de armas de destrucción masiva como residenciales (García de los Ríos y Jiménez-Gómez, 2007, p. 37). El edificio conocido como Satyan 7 era capaz de producir sarín a escala militar, aunque también cultivaban y producían otro tipo de armas biológicas, como: Toxina botulinica, Bacillus anthracis, Vibrio cholerae y Coxiella burnetii (García de los Ríos y Jiménez-Gómez, 2007, p. 37). El problema es que no disponían del personal cualificado que requería el proceso, saber dispersar adecuadamente los agentes biológicos, por ello intentaron reclutar a técnicos rusos (García de los Ríos y Jiménez-Gómez, 2007, p. 35). Pero ante la dificultad de poner en marcha la producción de sarín a gran escala, empezó a trabajar en la síntesis de VX (Pita, 2008, p. 457). Así, este agente fue utilizado en al menos cuatro ocasiones, desde noviembre de 1994 hasta febrero de 1995, en ataques selectivos contra personas consideradas enemigas de la organización, como las que intentaban rescatar a sus familiares ( $\mathrm{Tu}$, 2002). Los atentados consistían en poner en contacto al individuo con 
VX mediante la aplicación de pañuelos impregnados con dicho agente o mediante el uso de jeringas que disparaban un chorro de este (Pita, 2008, p. 457). Aunque solo en una ocasión lograron asesinar a un objetivo.

\subsubsection{Secta Bhagruan Shree Rajneesh}

En septiembre de 1984 se produjo un importante brote de salmonelosis (salmonella typhimurium) en la zona donde residía la secta Bhagwan Shree Rajneesh (Señor Dios del Universo). Este brote se originó simultáneamente en diez restaurantes y afectó a cerca de 751 personas, algunas de las cuales tuvieron que ser hospitalizadas. Parece ser que la manera de inocular este agente fue por medio del rociado directo sobre ensaladas y demás alimentos, o indirecto mediante la manipulación de condimentos y aliños que añadían a la comida. Lo curioso del caso es que las personas afectadas habían consumido alimentos con ingredientes de diversos orígenes y preparados por distintos restaurantes. Pese a esto, la investigación concluyó que no había habido una contaminación deliberada de los alimentos. Pero un año después, el 16 de septiembre de 1985, el dirigente de la mencionada secta, Bhagwan Shree Rajneesh acusó a varios de sus correligionarios.

La adquisición de microorganismos, por parte de esta secta, corría a cargo de Ma Anand Puja, la enfermera que era responsable del centro médico de la organización. Ella fue la que compró la cepa de Salmonella typhimurium al laboratorio llamado "VWR Scientific". Pero también adquirió en la American Type Culture Collection (ATCG) una serie de bacterias como, por ejemplo: Salmonella typhi, Salmonella paratyphi, Francisella tularensis, Shigella dysenteriae, Neisseria gonorrhoeae y Enterobacter cloacae.

\subsubsection{Amerithrax}

El 18 de septiembre de 2001 dos cartas esporas de Bacillus anthracis fueron depositadas en Trenton (Nueva Jersey), una dirigida al The New York Post y otra a Tom Brokaw de la NBC. Otras dos cartas fueron enviadas, el 9 de octubre de 2001, a Washington, destinadas a los senadores Tom Daschle, de Carolina del Norte, líder demócrata del Senado, y Patrick Lehay, de Vermont, Presidente de la Comisión de Justicia. Los 
cuatro sobres tenían el timbre postal y fueron clasificados en las instalaciones de correo de Hamilton Township, cerca de Trenton, antes de ser enviados a otros centros de procesamiento y distribución. Los dirigidos a los dos senadores se procesaron en las instalaciones de Brentwood en Washington. Existían indicios de que, por lo menos, las otras tres cartas con ántrax fueron enviadas, pero se perdieron o fueron desechadas. Hubo casos confirmados de carbunco cutáneo en las oficinas de la American Broadcasting Company (ABC) y de la Columbia Broadcasting System (CBS) en Nueva York y de carbunco por inhalación en la American Media Incorporated (AMI) en Boca Ratón, Florida. Varios individuos en las tres localidades cayeron enfermos antes del 9 de octubre, lo cual permite suponer que las tres cartas que no se recuperaron se pusieron al correo junto con las dos del 18 de septiembre que sí se rescataron.

Las cuatro cartas que se encontraron incluían las palabras "Ala es grande" (Allah is great) y la fecha "09-11-01", el día de los ataques con aeronaves contra el World Trade Center en Nueva York y el Pentágono en Virginia, aparentemente con la intención de presentar al remitente como un terrorista islámico. Las dos cartas fechadas el 18 de septiembre y la carta remitida al senador Daschle se recuperaron en las oficinas de los destinatarios. Pero la carta al senador Leahy, la cual había sido enviada por error al Departamento de Estado, fue descubierta en noviembre, únicamente después de una búsqueda de correo gubernamental sin abrir, recolectado en el Capitolio de los Estados Unidos y depositado en 635 bolsas para basura, que luego fueron selladas e inspeccionadas individualmente en busca de esporas de ántrax. Se encontraron 62 bolsas contaminadas, una mucho más que las otras. El examen individual de las cartas condujo al descubrimiento de la carta para el senador Leahy.

La primera víctima fue el periodista Robert Stevens, de American Media, de Boca Ratón (Florida). El segundo caso, también se produjo en la misma empresa de la primera víctima, pero fue por contagio, ya que cada persona que contrae esta enfermedad necesita inhalar su propia dosis infecciosa de la bacteria. Días después, se registraron cinco casos más. Al mismo tiempo, a un empleado del The New York Post le diagnosticaron carbunco cutáneo, al manipular la carta que iba dirigida a un periodista de ese periódico. El resultado final de este ataque bioterrorista 
fue de cinco fallecimientos y cerca de una veintena de casos confirmados de carbunco, todos ellos en EE.UU. Aunque los culpables nunca fueron identificados, tras el análisis genético se pudo concluir que la cepa a la que pertenecían las bacterias era la cepa Ames, aislada en los años 50 en Texas, pero nunca se ha sabido el laboratorio que la produjo.

La investigación criminal para descubrir al culpable de estos hechos fue conocida como el caso, Amerithrax, y ha sido una de las investigaciones más largas y caras. El análisis pericial grafonómico y sociolingüístico de las cartas concluyó que las misivas dirigidas a Tom Brokaw, al NY y al senador Daschle fueron escritas por la misma persona, siendo las cartas 1 y 2 copias idénticas, mientras la 3 con un mensaje algo diferente contenía un ántrax mucho más refinado y potente (Puente, 2010, p. 27). Aunque todo el material derivaba de la misma cepa bacteriana conocida como Cepa Ames. Estas pruebas y otras apuntaban a que al menos uno de los responsables fue el científico Bruce Ivins, que trabajaba como especialista en biodefensa para las fuerzas armadas estadounidenses. $\mathrm{Al}$ mes de comunicarle que era el principal sospechoso se suicidó. No obstante, habría que advertir que todavía quedan muchos puntos oscuros y muchas preguntas sin contestar.

\subsubsection{Al Qaeda}

El primer atentado con este tipo de armas fue el atentado en el World Trade Center en febrero de 1993. Los explosivos empleados en esta acción fueron mezclados con cianuro. La fortuna fue que el cianuro sódico en vez de quemarse se evaporó, porque si no todas las personas que se encontraban en la torre norte habrían muerto. Pero la evidencia de que $\mathrm{Al}$ Qaeda disponía de un programa químico y biológico se encontró cuando algunos periodistas y las fuerzas militares en Afganistán descubrieron documentos escritos y electrónicos con procedimientos rudimentarios para la fabricación de agentes químicos de guerra (Pita, 2007, p. 465). Asimismo, se conocía que el campo de Abu Khabab era un lugar de entrenamiento especializado en armas químicas (Gunaratna y Acharya, 2006). Hecho que se vio corroborado en una grabación donde se podía ver varias personas saliendo rápidamente de una habitación dentro de la cual se encuentra un perro atado (Pita, 2007, p. 467). Al 
poco tiempo aparece un vapor de color blanco y después el perro empieza a mostrar los primeros signos de intoxicación (Pita, 2007, p. 467).

Uno de los principales descubrimientos que aportaría más información sobre el programa de armas química de Al-Qaeda lo realizó el periodista Alan Cullison, del Wall Street fournal, en Kabúl (Cullison e Higgis, 2001). Este periodista compró dos ordenadores que, según el vendedor, había robado de la oficina de Muhammad Atef (Abu Hafs), líder militar de $\mathrm{Al}$ Qaeda y uno de los principales defensores de la adquisición de armas NBQ, muerto en noviembre de 2001 en Afganistán (Pita, 2008, p. 468). En estos dos ordenadores se encontraron documentos que describían el intento de iniciar un programa de armas químicas y biológicas, denominado "al Zabadi" ("Yogur") (Pita, 2008, p. 468), que se puso en marcha poco después del bombardeo estadounidense contra las bases de entrenamiento de terroristas en 1998, a raíz de los atentados contra las embajadas de Kenia y Tanzania.

Además, durante años se ha estado especulando sobre la posibilidad de que Ben Laden estuviera reclutando a químicos y biólogos de los antiguos países del Este y Pakistán. Una nota escrita por Zawahiri, en abril de 1999, lamenta la lentitud de la organización en darse cuenta del potencial de esas armas: "A pesar de su extremado peligro, solo nos hemos dado cuenta de ello cuando el enemigo nos ha llamado la atención con su insistencia sobre lo simple que resulta producirlas" (El País, 03/01/2002), asegura el médico egipcio antes de enumerar un catálogo de agentes mortales, desde el ántrax hasta la fiebre de las Montañas Rocosas. Otro texto escrito pocos días después, el 7 de mayo, indica que los dirigentes de $\mathrm{Al}$ Qaeda han destinado entre 2000 y 4000 dólares para el arranque del programa (El País, 03/01/2002). También hay mención a la visita a un tal Abu Jabab, el alias de un anciano científico egipcio.

Según fuentes del Pentágono, la organización de Ben Laden tiene un laboratorio en Derunta, una aldea cercana a Jalalabad, en el que se ha fabricado pequeñas cantidades de gas de cianuro. Además de este laboratorio, Al Qaeda tenía una planta fertilizante en Mazar-i-Sharif, y una planta para la producción de vacunas de antiántrax en Kabul. Pero los EE.UU. no son los únicos que sostienen que $\mathrm{Al}$ Qaeda posee armas 
químicas y biológicas, en este mismo sentido, también se manifestó el Ministro Británico de Asuntos Exteriores, Ben Bradshaw, al confirmar que la organización terrorista liderada por Osama Bin Laden, Al Qaeda, posee armas químicas y biológicas adquiridas durante los últimos 10 años, pero que se desconoce si tienen los medios necesarios para utilizarlas (El Mundo, 10/10/2001). Ese es precisamente el problema de apostar por armas químicas y biológicas, es decir, la necesidad de disponer de los sistemas de diseminación o dispersión adecuados, si el objetivo es producir un elevado número de víctimas (Pita, 2008, p. 469).

Además parece que los cookbooks no son capaces de resolver el problema de la dispersión de estos tipos de agentes. En estos se abordan con bastante éxito la producción de artefactos explosivos caseros, siendo los más conocidos los volúmenes: The Poor Man's James Bond de Kurt Saxon y los de la colección Scientific Principles of Improvised Warfare and Home Defense de Timothy Tobiason (Pita, 2008, p. 428). Además en la famosa Enciclopedia de la Yihad Afgana existe todo un capítulo sobre las armas químicas. En otros casos, los cookbooks tratan exclusivamente de sustancias tóxicas, como The Poisoner's Handbook, Silent death y Assorted nasties (Carus, 2002). No obstante, dada la falta de procedimientos y programas de producción de armas químicas adecuados explicarían por qué Al Qaeda no ha sido capaz hasta ahora de llevar a cabo un ataque químico de forma eficaz (Cánovas, 2011, p. 172).

\subsubsection{Grupos ecoterroristas}

En 1972, un grupo ecoterrorista llamado R.I.S.E, dirigido por dos estudiantes universitarios de Chicago, conspiró para erradicar a todo el género humano con ocho agentes patógenos distintos, para después repoblar el mundo con sus propios genes. Su plan original era usar unas avionetas para dispersar los agentes de la enfermedad en todo el mundo, pero con el tiempo redimensionaron sus planes para solo matar a los residentes de cinco Estados alrededor de Chicago, mediante la contaminación de las reservas de agua urbana. Pero finalmente, todo resultó fallido dado que algunos miembros del grupo avisaron al FBI del complot antes de que este se pudiera llevar a cabo. El resultado fue la huida de los dos cabecillas a Cuba. 


\subsubsection{Grupos terroristas de identidad cristiana}

En 1986 un grupo de "Identidad Cristiana" que estaba convencido de la supremacía de los blancos, conocido como The Covenant (La Alianza), The Sword (La Espada) y The Arm of the Lord (El Brazo del Señor), buscó derrocar al Gobierno federal y acelerar el regreso del Mesías. Para ello, adquirieron 30 galones de cianuro de potasio para envenenar las reservas urbanas de agua, ya que creían que Dios dirigiría el veneno de tal modo que solo mataría a los individuos no creyentes, además de los judíos y negros que vivían en las ciudades principales. El resultado fue que el FBI arrestó a sus líderes antes de que pudieran llevar a cabo sus actos. El motivo que llevó a esta organización a emplear agentes biológicos contra sus enemigos era emular las descripciones bíblicas que nos hablaban de la utilización divina de plagas para castigar al Faraón por no dejar que los israelitas abandonaran Egipto.

En 1995 un fundamentalista cristiano, convencido de que el Gobierno estadounidense formaba parte de una conspiración mundial contra los valores tradicionales, destruyó el Edificio Federal en Oklahoma City, causando la muerte a 168 personas, entre ellas 19 niños y 500 heridos. El culpable fue el exsoldado Timothy McVeigh, que había adquirido un enorme rencor contra el Gobierno estadounidense, primero, por su participación en la Guerra del Golfo Pérsico y, segundo, por el sistema imperante en EE.UU. cuando la Agencia de Control de Alcohol, Tabaco y Armas de Fuego atacó a la secta divina dirigida por Vernon Wayne Howell, quien había adoptado el nombre de David Koresh. En 1990 Vernon dijo que adoptó el nombre de David porque él había llegado a ser la cabeza bíblica de la Casa de David (el rey de Israel) y Koresh como apellido, debido a la traducción literal del idioma hebreo del nombre de Ciro, el rey de Persia, quien liberó a los judíos de la tiranía babilónica. Pero parece que Timothy McVeigh no fue el único culpable, ya que se especulaba que también había participado algún grupo terrorista de Oriente Medio.

\subsubsection{Grupos terroristas nacionalistas y separatistas}

Los grupos terroristas de carácter laico no parecen haber mostrado interés por las armas químicas y biológicas, dado que su uso podría pro- 
ducir el rechazo de sus propios seguidores (Pita, 2007, p. 420). No obstante, se conocen casos en los que grupos nacionalistas o separatistas han empleado este tipo de agentes para llevar a cabo atentados. Por ejemplo, en 1991 cuatro integrantes del Minnesota Patriots Council adquirieron ricina para asesinar a funcionarios del Internal Revenue Service (la oficina encargada de cobrar impuestos), a un "deputy Marshall" (asistente de alguacil) del Gobierno federal y a policías locales. El resultado fue que el FBI detuvo a los miembros del grupo antes de que pudieran llevar a cabo su plan. Otro caso similar fue cuando tres miembros pertenecientes a una escisión del grupo separatista "República de Texas", que creían que Texas fue ilegalmente anexada a EE.UU., fueron arrestados en una caravana en Omito (Texas), tras haber enviado correo electrónicos al FBI y a otros organismos oficiales norteamericanos declarando la "guerra" a EE.UU. y amenazando con utilizar armas químicas contra el presidente Clinton, los directores de la CIA y del FBI y el fiscal general, entre otros (Pita, 2011, p. 194).

Los miembros de los Tigres de Liberación del Eelam Tamil (LTTE) en Sri Lanka eran conocidos por llevar unas cápsulas de cianuro potásico que, por orden de Prabhakaran, debían utilizar si eran apresados. Pero también existen evidencias sobre ataques con cianuro a intereses económicos. En 1996 intentaron sabotear las exportaciones de té mediante comunicados a embajadas que informaban de que las partidas de esta infusión habían sido contaminadas con cianuro (Pita, 2007, p. 423). Otro atentado se produjo en diciembre de 1996, cuando habrían aplicado cianuro potásico a sellos de correo del ejército de Sri Lanka, con los que las tropas iban a enviar felicitaciones de Navidad a sus familiares (Pita, 2007, p. 423). Las Brigadas de los Mártires de al-Aqasa, el grupo más importante del movimiento nacionalista $\mathrm{Al}$ Fatah, también disponen de armas químicas y biológicas, gracias a que durante, aproximadamente, tres años se han dedicado a su producción, según han manifestado en el comunicado emitido el 25 de junio de 2006.

El grupo terrorista Hamas también ha manifestado su interés por las armas químicas, pudiendo acceder a alguna de ellas gracias a su labor social. No olvidemos, que Hamas dispone de hospitales que pueden conseguir algunas sustancias químicas de alta toxicidad, incluso, a través 
de ellos han producido algunos explosivos. Además, se cree que Siria podría estar vendiendo armas químicas a Hamas y Hezbolá, es más, se sabe que los rebeldes libios han vendido miles de bombas de gas mostaza y gas nervioso a esta misma organización terrorista. Una evidencia de que Hamas ya dispone de armamento químico y biológico se podría encontrar en su web, cuando en una declaración escrita de Abu Ahmad, líder militar de Hamas, pedía el reclutamiento de miembros con experiencia en armas químicas. No obstante, todavía no se ha registrado ninguna acción del grupo en este sentido, lo más ha sido el uso de cianuro en los ataques suicidas.

También, el PKK (Partido de los Trabajadores del Kllrdistán) contaminaba con cianuro potásico los depósitos de agua de una Base Aérea turca en Estambul, en marzo de 1992. Pero el plan fue descubierto antes de que se produjesen las intoxicaciones, ya que se encontraron dos recipientes de $25 \mathrm{~kg}$ de cianuro potásico al lado de los tanques y se comprobó que había una capa de espuma en el agua (Karasik, 2002, p. 18). En otra ocasión, esta vez en 1999, Adam Bushy, líder del Ejército de Liberación Nacional Escocés, envió cartas amenazando con contaminar los suministros de agua del Reino Unido con paraquat -la herbicida- si las tropas británicas no se retiraban de Irlanda del Norte antes de junio de 1999 (Gurr y Cole, 2000, pp. 279-280).

\subsection{El uso de armas biológicas y químicas}

Las armas biológicas y químicas son consideradas como la bomba atómica de los pobres. Si se sostiene tal afirmación es porque las armas biológicas son más baratas, ya que afectar un kilómetro cuadrado con armas convencionales costaría, en proporción, unos 2000 dólares, 800 con armas nucleares, 600 con armas químicas y 1 dólar con armas biológicas (González, 201 1, p. 103). Lo cual trasmite la impresión errónea de la facilidad en su preparación y utilización. No obstante, la naturaleza y el grado de peligro dependen de una multitud de factores que influyen en su toxicidad, contagiosidad o virulencia durante y después de su liberación, su desplazamiento y dilución en la atmósfera y el estado de protección y susceptibilidad de las personas expuestas. Desde el punto de vista técnico, las características entre agentes químicos y agentes 
biológicos son diferentes. Los agentes químicos normalmente provocan un cuadro agudo en el mismo lugar donde se produce la exposición al agente químico (Ibáñez, 2005, p. 8). Los biológicos tenderán a provocar el cuadro clínico en horas o días posteriores a la exposición, pues se contrae la enfermedad a raíz de la infección causada por el agente biológico, teniendo un mayor impacto en los socio-sanitarios (Ibáñez, 2005, p. 9). La detección de ambos agentes también es diferente; los biológicos carecerán de olor y de sabor y no dejan rastro en la ropa; por el contrario los químicos tendrán olor que puede ser apreciado y podrán dejar rastro en la ropa (Ibáñez, 2005, p. 9). Por último, los agentes biológicos son mucho más mortales que los químicos.

\subsubsection{Las armas biológicas}

Las armas biológicas son organismos vivos adaptados militarmente para causar enfermedades en humanos, animales o plantas (Soteras, 2008a). Así, son "aquéllas que alcanzan los efectos pretendidos por medio de la contagiosidad de microorganismos patógenos y otras entidades tales, incluso virus, ácidos nucleicos infecciones y priones" (Organización Mundial de la Salud, 2003, p. 4). Desde el punto de vista militar, un arma biológica es un "dispositivo que proyecta, dispersa o disemina un agente biológico, incluyendo artrópodos e insectos vehicularizadores en un campo de batalla o zona de operaciones, con el fin de neutralizar al enemigo" (Orientaciones de Defensa, 2000, p. 3). Las rutas de infección pueden ser el agua, los alimentos, el aire y los paquetes contaminados con microbios, bacterias, virus o toxinas. Además su capacidad de matar perdura en el tiempo, es más, si son descargadas por medio de granadas pueden persistir en forma mortal por décadas, haciendo la tierra inhabitable (Villamarín, 2005). Ya que según nos informa la Office of Technology Assessment (Oficina de Evaluación Tecnológica) del Congreso de los EE.UU., empleadas en cantidades equivalentes, las armas biológicas podrían ser más dañinas que las armas nucleares o las químicas (García de los Ríos y Jiménez-Gómez, 2007, p. 5).

Es más, en un estudio realizado en 1993 se hace una comparación de la extensión y mortandad desencadenada por diferentes armas de destrucción masiva portadas por un misil Scud sobre Washington D.C. en 
un día cubierto, de día o de noche y con viento moderado, es decir, ni en el mejor ni en el peor de los casos. El resultado fue el siguiente: $300 \mathrm{~kg}$ de gas sarín (arma química) se extenderían con una tasa de $70 \mathrm{mg}$ al min/ $\mathrm{m}^{3}$, llegaría a ocupar $0,22 \mathrm{~km}^{2}$ y producirían de 60 a 200 muerto; $30 \mathrm{~kg}$ de esporas de carbunco se extenderían con una tasa de $1 \mathrm{mg}$ al $\mathrm{min} / \mathrm{m}^{3}$, llegarían a ocupar $10 \mathrm{~km}^{2}$ y producirían de 30.000 a 100.000 muertos; una bomba atómica de 125 kilotones ocuparía $78 \mathrm{~km}^{2}$ y mataría entre 23.000 a 80.000 personas; y una bomba H de 1 megatón, ocuparía 190 $\mathrm{km}^{2}$ y causaría entre 570.000 a 1.900 .000 de muertos (US Congress, 1993, p. 53). El problema es que tardan más tiempo en hacer efecto que las demás armas aquí mencionadas.

Así, las características que debe poseer toda arma biológica son:

1. Ser muy letal o altamente incapacitante, ya que cuantas más muertes ocasionen mejor, dado que de esta forma no solo quedarían neutralizadas las personas incapacitadas, sino que habría que movilizar más personal sanitario, ambulancias, etc.

2. Ser fácil de obtener en grandes cantidades.

3. Ser fácil de introducir en armas, de ahí que se busquen microorganismos que sean especialmente resistentes a agentes físicos, como temperatura o desecación, para que se puedan introducir en el vehículo adecuado para su dispersión.

4. Ser dificil de detectar, al menos en los primeros momentos, como consecuencia que normalmente las armas biológicas presentan unos síntomas que pueden ser comunes a muchas enfermedades, y

5. Con gran impacto en la salud pública, causando pánico y alarma social (García de los Ríos y Jiménez-Gómez, 2007, p. 54).

Por otra parte, los agentes biológicos se clasifican comúnmente de acuerdo con su taxonomía, siendo los más importantes: los hongos, las bacterias y los virus. Pero también se pueden clasificar de acuerdo con las propiedades que determinan su utilidad para fines hostiles, como su facilidad de producción o su resistencia a las medidas terapéuticas y de 
profilaxis. De forma más general, se pueden clasificar según otras características, como su poder de infección, virulencia, periodo de incubación, letalidad, contagiosidad y mecanismos de transmisión y estabilidad, todas ellas influyen en su potencial como armas. Por ejemplo, hay toxinas pirógenas (que generan fiebre), citolíticas (que destruyen células), paralizantes, etc. Pero por el órgano o tejido afectado puede ser: neurotoxina, cuando actúa sobre el Sistema Nervioso Central, o enterotoxina, cuando su acción es sobre el intestino. Por la puerta de entrada al organismo pueden ser: por vía digestiva (penetran los diversos patógenos intestinales), vía respiratoria (lo hacen los agentes de neumonías), vía urogenital (los responsables de enfermedades de transmisión sexual), y a través de heridas. Aunque la clasificación que vamos a utilizar aquí, va ser la que hace los Centros para el Control y la Prevención de Enfermedades $(\mathrm{CDC})$. Esta clasificación incluye un heterogéneo conjunto de bacterias, virus, parásitos y toxinas, divididos en tres categorías (A, B y C) en función de su capacidad para causar enfermedad y muerte, su facilidad para diseminarse o ser diseminados más o menos fácilmente, el que sean capaces de producir pánico y alarma social y que requieran de la utilización de medidas extraordinarias por parte de los organismos sanitarios públicos (García de los Ríos y Jiménez-Gómez, 2007, p. 55-56).

\subsubsection{Agentes biológicos de Categoría A (con arreglo a su actuación)}

Los agentes biológicos de la categoría A son aquellos que pueden ser fácilmente trasmitidos de persona a persona y deben tener altas tasas de mortalidad. Por tanto, la enfermedad causada por el agente biológico debe ejercer gran impacto en la salud pública, produciendo pánico y generar disturbios sociales.

Entre los agentes de esta categoría están:

- Bacillus anthracis (Carbunco=Ántrax). Bacteria famosa por el ataque bioterroristas que se produjo en EE.UU. tras el 11 de septiembre de 2001.

- Clostridum botulinum (Botulismo) es el veneno más potente de la naturaleza. 
- Yersinia pestis (Peste), una infección bacteriana con elevadas tasas de mortandad.

- Variola mayor (Viruela), una enfermedad erradicada con una mortandad superior al 30\%.

- Francisella tularensis (Tularemia), una bacteria causante de una grave zoonosis asociada a animales salvajes.

\section{Tabla 1. Agentes Categoría A}

\begin{tabular}{|c|c|c|c|c|}
\hline AGENTE & $\begin{array}{l}\text { VÍAS DE INFEC- } \\
\text { CIÓN } \\
\text { Y DISEMINA- } \\
\text { GIÓN MÁS EFI- } \\
\text { GIENTE }\end{array}$ & $\begin{array}{c}\text { TASA } \\
\text { DE MORTA- } \\
\text { LIDAD }\end{array}$ & $\begin{array}{l}\text { PERIODO } \\
\text { DE INGU- } \\
\text { BACIÓN }\end{array}$ & $\begin{array}{l}\text { INMUNOPROFI- } \\
\text { LAXIS Y } \\
\text { QUIMIOPROFI- } \\
\text { LAXIS }\end{array}$ \\
\hline $\begin{array}{c}\text { Bacillus anthracis } \\
\text { (Carbunco=Ántrax) }\end{array}$ & $\mathrm{C}, \mathrm{G}, \mathrm{I} /$ aerosol & $\begin{array}{c}\mathrm{C}<25 \% \\
\mathrm{I}>95 \%\end{array}$ & 1 a 4 días & $\begin{array}{c}\text { Vacuna/ } \\
\text { antibióticos } \\
\text { (efectivos si se } \\
\text { administran en } \\
\text { fase precoz) }\end{array}$ \\
\hline $\begin{array}{l}\text { Clostridum botu- } \\
\text { linum (Botulismo) }\end{array}$ & $\mathrm{G}$, & & 1 a 15 días & Antitoxina \\
\hline $\begin{array}{l}\text { Yersinia pestis } \\
\text { (Peste) }\end{array}$ & $\begin{array}{l}\text { I, V/aerosol o } \\
\text { Vectores }\end{array}$ & $\begin{array}{l}\text { Bubóni- } \\
\text { ca-50\% } \\
\text { Neumóni- } \\
\text { ca-50/90\% }\end{array}$ & 2 a 3 días & $\begin{array}{l}\text { No vacuna/ } \\
\text { antibióticos }\end{array}$ \\
\hline $\begin{array}{c}\text { Variola mayor } \\
\text { (Viruela) }\end{array}$ & $\mathrm{CD}$, & $30 \%$ & 7 a 21 días & Vacuna \\
\hline $\begin{array}{l}\text { Francisella tularen- } \\
\text { sis (Tularemia) }\end{array}$ & $\begin{array}{c}\mathrm{C}, \mathrm{G}, \mathrm{I}, \mathrm{V}, \mathrm{CD} / \\
\text { aerosol }\end{array}$ & $30-40 \%$ & 1 a 10 días & $\begin{array}{l}\text { Vacuna/ } \\
\text { antibiótico }\end{array}$ \\
\hline
\end{tabular}

Fuente: (Ibáñez, 2005, p. 36).

C: cutánea; G: gastrointestinales; I: inhalación; V: vector; GD: contacto directo.

\subsection{El carbunco}

El carbunco es una enfermedad de origen telúrico, contagiosa, aguda y grave que afecta a los herbívoros, tanto domésticos como salvajes, siendo rara la enfermedad en la especie humana. Los animales, normal- 
mente, contraen la enfermedad por ingestión de esporas al alimentarse de hierba en suelos contaminados. Así, las personas que se suelen contagiar son aquellos que trabajan con animales y entran en contacto con infectados.

En cualquier caso, el hombre puede desarrollar tres tipos de enfermedades en relación con esta bacteria:

a. Carbunco cutáneo

El carbunco cutáneo es una infección de la piel causada por el contacto directo con la bacteria Bacillus anthracis. El riesgo para contraerlo reside en el contacto con pieles y pelajes animales, productos óseos y lana, o animales infectados, siempre y cuando se rozan con cortaduras o raspaduras de la piel. Los síntomas son una ampolla o úlcera, que posteriormente forma una costra negra y que por lo general está rodeada de mucha hinchazón.

b. Carbunco pulmonar

El carbunco por inhalación o pulmonar es una rara enfermedad, de la que se han conocido muy pocos casos clínicos a lo largo de la historia, dado que es difícil que se den las condiciones naturales para que se establezca la enfermedad (García de los Ríos y Jiménez-Gómez, 2007, p. 100). El carbunco afecta comúnmente a los animales ungulados, como ovejas y cabras, pero los humanos también lo pueden adquirir, siempre que inhalen esporas aerotransportadas en los procesos industriales, como la curtiduría de pieles y procesamiento de la lana. Sus síntomas comienzan con fiebre, malestar, dolor de cabeza, tos, insuficiencia respiratoria y dolor de pecho.

c. Carbunco por ingestión

El carbunco por ingestión es una enfermedad también rara, que se produce cuando alguien ingiere carne contaminada con carbunco. La enfermedad suele desarrollarse en una semana y puede afectar la boca, el esófago, los intestinos y el colón. La infección se puede diseminar al torrente sanguíneo y puede causar la muerte. Sus síntomas son náuseas, vómitos y diarrea sanguinolenta. 
Es un agente ideal para la guerra biológica y el bioterrorismo, ya que se caracteriza por ser muy letal o altamente incapacitante, con una tasa de mortandad que ronda el $85 \%$; ser fácil de obtener en grandes cantidades, ya que crece en simples caldos nutritivos; ser fácil de introducir en armas, dado que son especialmente resistentes a agentes físicos, como temperatura o desecación, y se pueden introducir fácilmente en vehículos adecuados para su dispersión. Tal es así, que en los diferentes programas ofensivos de los ejércitos que los han tenido, la producción biológica estaba ligada a la fabricación de obuses, bombas de aviación, misiles, métodos de dispersión acoplados a aviones de combate, entre otros; ser difíciles de detectar, al menos en los primeros momentos, ya que esta enfermedad presenta unos síntomas que pueden ser comunes a muchas otras; y su impacto ha llegado a ser amplificado hasta límites inimaginables en todo el mundo (García de los Ríos y Jiménez-Gómez, 2007, p. 105).

El primer ataque bioterroristas con ántrax se produjo el 18 de septiembre, cuando las cartas con esporas de Bacillus anthracis fueron depositadas en la estafeta de Trenton (Nueva Jersey), infectando a 22 personas, 7 sobrevivientes, como ya se ha explicado en el apartado anterior. Además se creen que al menos 17 países tienen un programa de biológicas con carbunco.

\subsection{El Botulismo}

Se trata de una enfermedad neurológica severa caracterizada por una parálisis fláccida que afecta a los humanos y a una variedad de animales, causada por la acción de la neurotoxina botulínica. El concepto aceptado sobre la patógena ha sido que se trata de una intoxicación alimentaria provocada por la ingestión de la toxina preformada en alimentos procesados en forma incorrecta y más rara de la producción in vivo de la toxina a nivel de una herida.

Existen, actualmente, cinco formas de botulismo: 
a. Intoxicación alimentaria

La intoxicación alimentaria es la forma más común del botulismo, y es consecuencia de la ingesta de alimentos que contienen la toxina. El período de incubación varía entre unas horas y 8-10 días, aunque lo más frecuente son 1-3 días. El cuadro puede ser de leve a mortal y se caracteriza por la aparición de manifestaciones neurológicas musculares y de disfunción autónoma. Los síntomas son: debilidad general a nivel ocular: diplopía, visión borrosa por dificultad en la acomodación, fotofobia, midriasis, pupilas fijas y sequedad del ojo; a nivel digestivo: disfagia y sequedad de boca, lengua y faringe, estreñimiento, náuseas y vómitos. Por afectación vegetativa pueden aparecer retención urinaria e hipotensión postural. En la mayoría de los casos la muerte sobreviene por fallo respiratorio, debido a la afectación de músculos respiratorios o neumonía.

b. Botulismo de heridas

El botulismo de heridas se produce por infección de heridas con esporas ambientales. La mayoría de las heridas pre-botulínicas son traumáticas, pero la enfermedad también se ve con frecuencia asociada a heridas en pacientes adictos a drogas. La incubación es un poco más larga, de 4-14 días y las manifestaciones son similares aunque los síntomas gastrointestinales suelen estar ausentes.

c. Botulismo del lactante

El botulismo del lactante aparece entre la semana y los 12 meses de vida y se vincula a la ingestión de esporas. La fuente de las mismas puede ser a través de la ingestión de miel u otros jarabes azucarados contaminados con esporas. La enfermedad comienza con estreñimiento, indiferencia a estímulos, pérdida de apetito, ptosis (párpados caídos), dificultad para deglutir, pérdida del control de la cabeza e hipotonía, que evoluciona a debilidad generalizada (bebé laxo), letargia, llanto débil y en algunos casos insuficiencia y parada respiratoria. 
d. Botulismo escondido o de origen desconocido

El botulismo escondido o de origen desconocido puede ser la variante adulta del botulismo del lactante y ocurre en adultos que usualmente tienen alguna anormalidad del tracto intestinal que permite la colonización por parte de C. botulinum.

e. Botulismo inadvertido

El botulismo "inadvertido" es la forma más recientemente descrita. Puede ocurrir en pacientes tratados con inyecciones de toxina botulínica por desórdenes del movimiento.

Las características de este agente como arma biológica son las siguientes: es el veneno más potente de la naturaleza, aunque no es tan sencillo como otros agentes, se puede producir sin grandes dificultades si se conoce bien cuáles son las condiciones que se requieren; es dificil de detectar y producen un gran efecto. El problema es que no es fácil de introducir en armas, ya que al tratarse de proteínas, es sensible a la temperatura y a la luz solar, por tanto, se destruye y seca fácilmente si está expuesta al aire y a la luz (García de los Ríos y Jiménez-Gómez, 2007, pp. 140-141).

Esto hace que, pese a estas pequeñas dificultades, esta toxina haya formado parte de los arsenales biológicos de los países productores. Por ejemplo, en 1990 Irak reconoció a los inspectores de la ONU haber producido 19.000 litros de toxina botulínica concentrada, de los que 10.000 había sido vehiculizados (García de los Ríos y Jiménez-Gómez, 2007, p. 142). Estados Unidos y la antigua Unión Soviética también la poseen. Además, según fuentes de EE.UU., científicos de la ex Unión Soviética han sido reclutados por otros países donde se cree que también han desarrollado estas armas, como: Irán, Corea del Norte y Siria. Por otra parte, el primer atentado bioterroristas con esta toxina se produjo en abril de 1990, cuando los miembros de la secta de Sohoko Asahara dispersaron alrededor del parlamento japonés de Tokio, como ya se hizo mención en el apartado anterior. No obstante, un gramo de toxina botulínica dispersada para ser inhalada puede matar a más de 1.000 .000 de personas, afortuna- 
damente diversos problemas técnicos hacen difícil esta forma de dispersión.

\subsection{La Peste}

La Peste es una enfermedad infectocontagiosa que afecta tanto a animales como a humanos, causada por la bacteria Yersinia pestis. Se considera una de las zoonosis (que es cualquier enfermedad que puede trasmitirse de animales a seres humanos) reconocida más antigua y una de las más agresivas y potencialmente letales enfermedades bacterianas. Aunque se conocen más de 200 especies de mamíferos que pueden ser infectados con esta bacteria, son los roedores los reservorios más significativos y los únicos que tienen importancia a largo plazo desde un punto de vista epidemiológico, ya que el vector de la enfermedad es la pulga de la rata. Así, la mayoría de los contagios se producen por la picadura de pulgas procedentes de roedores, pero también se pueden producir a partir de la mordedura o arañazos de gatos y otros carnívoros, por ingestión de animales muertos, por la manipulación de cadáveres de animales afectados por la enfermedad, o por la inhalación de bacterias a partir de la forma neumónica humana (peste dímica).

Normalmente, se pueden producir cuatro formas de la peste:

a. Peste bubónica

La peste bubónica es una enfermedad infecciosa aguda, causada por el Bacilo de Yersin. Es la más común de todas las pestes y es la que se transmite a través de una pulga que, infectada a partir de un roedor, pica a una persona o, más raramente, mediante objetos contaminados a través de heriditas en la piel (García de los Ríos y Jiménez-Gómez, 2007, p. 114). Esta enfermedad se caracteriza porque aparecen bulbos o bubones en los ganglios (axilas, ingles y cuello), es muy dolorosa, y suele llegar a ulcerarse, con necrosis abundantes y hemorragias. Debido a estas inflamaciones brotan en la piel bubones secundarios, formándose ampollas y pústulas azuladas. La mortandad de esta enfermedad puede llegar a alcanzar el $60 \%$. 
b. Peste neumónica

La peste neumónica o pulmonar aparece cuando la bacteria va a parar a los pulmones por inhalación microgotas procedentes de las vías respiratorias de una persona o animal que sufre la misma enfermedad (García de los Ríos y Jiménez-Gómez, 2007, p. 115). Sus síntomas son los mismos que una neumonía, salvo la inflación de los ganglios.

c. Peste septicémica

La peste septicémica se produce cuando un microorganismo, inoculado por la pulga, se multiplica solo en la sangre, aunque sin producirse bubones, o también por extensión de la peste neumónica. Los síntomas son gangrena, causada por una trombosis, en los puntos más dístales, como los dedos de la mano y los pies y la punta de la nariz (García de los Ríos y Jiménez-Gómez, 2007, p. 115).

d. Peste neurológica

Es la menos frecuente y se produce por complicaciones de la peste septicémica.

La peste se adapta bien a las características de arma biológica, ya que mata más que casi todos los agentes conocidos, no presenta dificultades especiales para crearla, es difícil de detectar porque su periodo de incubación es corto y cuando se diagnostica el daño ya está hecho, y genera un gran impacto sobre la población. El único inconveniente es que es difícil de introducir en armas, dado que tiene una baja resistencia a los factores ambientales como la temperatura, el sol, entre otros (García de los Ríos y JiménezGómez, 2007, p. 116). Así, habría que mencionar que en caso de ser utilizada como arma biológica, la diseminación de esta toxina sería por aerosol. Por tanto, se produciría una epidemia de peste, cuyos síntomas serían inicialmente semejantes a una enfermedad respiratoria severa, aunque la magnitud del brote dependería de la cantidad del agente biológico, las características de la cepa, las condiciones ambientales y el método de aerolización. 


\subsection{La viruela}

La viruela es una enfermedad infecciosa grave, contagiosa, causada por el Variola virus, que en algunos casos puede causar la muerte. Su nombre proviene del latín varius (variado, variopinto) y se refiere a los abultamientos que aparecen en la cara y en el cuerpo de una persona infectada. La enfermedad se contrae por vía respiratoria, pero también a través de la ropa de cama, toallas, objetos que estén en contacto con el enfermo. El virus es resistente a soluciones diluidas de fenol y otros desinfectantes comunes, no obstante, puede ser inactivado por disolventes lipófilos apolares, como el cloroformo, por calentamiento a $60^{\circ} \mathrm{C}$ durante 10 minutos o esterilizando en autoclave (García de los Ríos y JiménezGómez, 2007, p. 66).

El virus de la viruela puede ser un candidato ideal para ser usado en la guerra biológica y el bioterrorismo, porque puede ser un arma muy letal o altamente incapacitante, dado que como se puede comprobar en la tabla 1, su tasa de mortandad se puede elevar hasta el 30\%; ocasiona pocos problemas de producción, ya que ha sido producida por la antigua URSS, llegándose a almacenar 20 toneladas en Zagorsk en su arsenal de armas biológicas de la década de 1970, y hacia 1990 disponía de una planta capaz de producir de 80 a 100 toneladas anuales de virus (Alibek y Handleman, 1999, pp. 261-264); es fácil de introducir en armas, ya que se trasmite por vía área; es difícil de detectar, dado que desde que se entran en contacto con el virus hasta que aparecen los primeros síntomas pasan un gran número de días; y generan un gran impacto en la salud pública (García de los Ríos y Jiménez-Gómez, 2007, p. 63).

En todo caso, este virus ha sido producido por algunos gobiernos, a parte de la Unión Soviética, para una hipotética guerra biológica. Así, en 1956 el Gobierno de EE.UU., al conocer la existencia del programa soviético de armas biológicas, empezó a cambiar sus preferencias en su programa por enfermedades bacterianas víricas (Bourzac, 2002). De tal manera, que en mayo de 1965 se probaron atomizadores cargados con falsos virus, ocultos en portafolios en el Washington International Airport (García de los Ríos y Jiménez-Gómez, 2007, p. 80). Los científicos calcularon que, si el virus hubiera sido real, uno de cada 12 viajeros ha- 
bría terminado infectado (García de los Ríos y Jiménez-Gómez, 2007, p. 80). Téngase en consideración que no sería la primera vez que se emplearía la viruela como arma biológica, ya que los británicos durante la Guerra Franco-India (1754-1763) contra Francia y sus aliados nativos americanos, ofrecieron dos mantas y un pañuelo, que había estado expuesto a la viruela, a los representantes de los delawares con el objetivo de difundir la enfermedad y concluir con el asedio.

Incluso se ha llegado a efectuar un simulacro de ataque bioterroristas, denominado Dark Winter, que se realizó entre el 22 y el 23 de junio de 2001. El simulacro consistía en un ataque bioterroristas empleando el virus de la viruela, para ello, se infectaba a tres personas en tres lugares distintos de EE.UU., esto obligó a reunirse al Consejo Nacional de Seguridad para poder dar solución al problema, más cuando en cuestión de horas se habría extendido por miles de personas. Al ser considerada como una enfermedad erradicada, no está contemplada en los esquemas de vacunación. La finalidad de este experimento fue incrementar la toma de conciencia entre los expertos en seguridad sobre el alcance de la amenaza que supone este tipo de armas, y por tanto, desencadenar acciones que mejoren la prevención y las estrategias de la respuesta (García de los Ríos y Jiménez-Gómez, 2007, p. 80). De esta manera, el gobierno de George W. Bush negoció con cuatro compañías farmacéuticas la producción, para el 2002, de 300 millones de dosis de la vacuna contra la viruela.

\subsection{La tularemia}

La tularemia o fiebre de los conejos es una enfermedad infecciosa potencialmente causada por la bacteria Francisella tularensis, que se encuentra en los animales salvajes, especialmente los roedores, los conejos y las liebres, aunque también se puede presentar en otros mamíferos. Se trasmite por contacto físico con el cuerpo del animal infectado, sobre todo a través de heridas y mucosas, pero también por picaduras de diversos antrópodos (insectos, arácnidos, crustáceos y miriápodos), por el agua contaminada y por inhalación. Los síntomas varían, dependiendo de la ruta de introducción. En esos casos en que la persona ha sido infectada tocando cadáveres de los animales, los síntomas pueden incluir úlceras que se desarrollan lentamente en el sitio donde la bacteria ha 
penetrado la piel, e inflamación de los ganglios linfáticos. Cuando la bacteria ha sido inhalada, la persona desarrolla una enfermedad parecida a la neumonía. Las personas que ingieren la bacteria pueden reportar dolores de garganta, dolor abdominal, vómito y diarrea.

Como en otros casos, este agente resulta ser una perfecta arma biológica, ya que resulta ser un microorganismo muy virulento, dado que puede causar la mortandad al 30-60\% de los enfermos que padecen esta enfermedad, es fácil de crear, difícil de diagnosticar, porque al igual que la peste, cuando se hace el daño ya está hecho, y produce un gran impacto. Pero, sin embargo, al igual que la peste es difícil de introducir en las armas por ser una bacteria no esporulada (García de los Ríos y Jiménez-Gómez, 2007, p. 122). Tal es así, que se presume que la bacteria puede haber sido ocupada intencionalmente durante la Segunda Guerra Mundial, a raíz de un brote ocurrido entre soldados de la Unión Soviética y alemanes. Entre 1950 y 1960, Estados Unidos investigó su diseminación en forma de aerosol, conduciendo a la producción de una vacuna atenuada que resultó parcialmente efectiva, y a tratamiento profiláctico con estreptomicinas, tetraciclinas y Cloranfenicol. En 1990 la Unión Soviética habría producido cadenas de F. tularensis resistentes a antibióticos y vacunas $(2,4,19,21)$.

\subsubsection{Agentes biológicos de Categoría B (por sus propiedades)}

Los agentes biológicos de la categoría B son aquellos moderadamente fáciles de diseminar, con moderada tasas de morbilidad y bajas tasas de mortalidad.

Entre los agentes de esta categoría están:

- Brucella (brucelosis), es una bacteria que causa las fiebres de Malta, zoonis con baja tasa de mortandad pero que provocan gran incapacidad.

- Clostridium perfringens (toxina épsilon), una toxina que forma poros que atraviesan la membrana de la célula.

- Salmonella, Escherichia coli, Shigella (amenazas contra la seguridad de los alimentos), pueden causar desde trastornos intestinales hasta 
fiebres tifoides, con tasas de mortandad de 1-21\%.

- Burkholderia mallei (muermo), enfermedades de origen que podrían trasmitirse a humanos, y sus tasas de mortandad son superiores al $50 \%$.

- Burkholderia pseudomallei (melioidosis), enfermedades de origen animal que podrían trasmitirse a humanos, y sus tasas de mortandad son de $19-46 \%$.

- Chlamydia psittaci (psitacosis), bacteria, parásita intracelular, parásita intracelular, causante de la llamada psitacosis-ornitosis, una neumonía transmitida por aves con un $20 \%$

- Coxiella burnetii (fiebre Q), bacteria, parásita intracelular, causante de la llamada fiebre $Q$, una neumonía asociada a diversos animales, con tasas de mortandad del 12\%.

- Ricinus communis (semilla de ricino), la planta de la que se obtiene el aceite de ricino, siendo un potente veneno que se puede trasmitir por inhalación, por ingestión o por inyección.

- Staphylococcus aureus (enterotoxina B), es una toxina que cuando se libera en el intestino produce trastornos muy limitados, trasmitida por inhalación podría ser grave.

- Rickettsia prowazekii (tifus), bacteria, parásita intracelular, causante del grave tifus exantemático epidémico, transmitido por piojos, con tasas de mortandad de $10-40 \%$.

- Encefalitis esquina venezolana, encefalitis esquina del Este y la encefalitis esquina del Oeste (Encefalitis víricas por alfavirus).

- Cryptosporidium parvum (amenazas contra la seguridad del agua), protozoo parásito intracelular, asociado a diarreas. 
Tabla 2. Agentes Categoría B

\begin{tabular}{|c|c|c|c|}
\hline Toxina & $\begin{array}{l}\text { Origen } \\
\text { natural }\end{array}$ & $\begin{array}{l}\text { Manifestación } \\
\text { de los efectos }\end{array}$ & Síntomas \\
\hline Brucelosis & Brucella & 1-6 semanas & $\begin{array}{l}\text { Fiebre, dolor abdomi- } \\
\text { nal, dolor de espalda, } \\
\text { escalofríos, sudoración } \\
\text { excesiva, fatiga, dolor } \\
\text { de cabeza, inapetencia, } \\
\text { debilidad, entre otros. }\end{array}$ \\
\hline $\begin{array}{l}\text { Toxina } \\
\text { épsilon }\end{array}$ & $\begin{array}{l}\text { Clostridium } \\
\text { perfringens }\end{array}$ & $7-15$ horas & $\begin{array}{l}\text { Nauseas, vómitos, dia- } \\
\text { rrea, dificultades res- } \\
\text { piratorias, tos, dolor } \\
\text { punzante, sarpullido, } \\
\text { ampollas, entre otros. }\end{array}$ \\
\hline Salmonella & Salmonella typhi & 8-48 horas & $\begin{array}{l}\text { Dolor de cabeza, dolor } \\
\text { abdominal, diarrea, fie- } \\
\text { bre, náusea. }\end{array}$ \\
\hline Muermo & $\begin{array}{l}\text { Burkholderia } \\
\text { mallei }\end{array}$ & 1-5 días & $\begin{array}{l}\text { Fiebre, dolores muscu- } \\
\text { lares, dolor de cabeza, } \\
\text { etc. }\end{array}$ \\
\hline Melioidosis & $\begin{array}{l}\text { Burkholderia } \\
\text { pseudomallei }\end{array}$ & 1-14 días & $\begin{array}{l}\text { Tos, infección pulmo- } \\
\text { nar, fiebre, cefalea, do- } \\
\text { lor torácico y dolores } \\
\text { musculares. }\end{array}$ \\
\hline Psitacosis & $\begin{array}{l}\text { Chlamydia } \\
\text { psittaci }\end{array}$ & 4-15 días & $\begin{array}{l}\text { Fiebre, dolor de cabe- } \\
\text { za, escalofríos, diarrea, } \\
\text { secreción ocular y na- } \\
\text { sal, entre otros. }\end{array}$ \\
\hline Fiebre Q & Coxiella burnetii & 2-3 semanas & $\begin{array}{l}\text { Tos, fiebre, dolor de } \\
\text { cabeza, dolores muscu- } \\
\text { lares, dolor abdominal, } \\
\text { dolor torácico, erup- } \\
\text { ción cutánea. }\end{array}$ \\
\hline
\end{tabular}




\begin{tabular}{|c|c|c|c|}
\hline Toxina & $\begin{array}{l}\text { Origen } \\
\text { natural }\end{array}$ & $\begin{array}{l}\text { Manifestación } \\
\text { de los efectos }\end{array}$ & Síntomas \\
\hline $\begin{array}{l}\text { Semilla de } \\
\text { ricino }\end{array}$ & $\begin{array}{l}\text { Ricinus } \\
\text { communis }\end{array}$ & 6-8 horas & $\begin{array}{l}\text { Tos, presión en el pe- } \\
\text { cho, dificultad al respi- } \\
\text { rar, dolores musculares, } \\
\text { vómitos, diarrea, para- } \\
\text { lización hígado, riñones } \\
\text { y bazo. }\end{array}$ \\
\hline $\begin{array}{c}\text { Enterotoxina } \\
\text { B }\end{array}$ & $\begin{array}{c}\text { Bacteria } \\
\text { Staphylococcus } \\
\text { aureus }\end{array}$ & 1-12 horas & $\begin{array}{l}\text { Fiebre, escalofríos, tos, } \\
\text { náuseas, debilidad, vó- } \\
\text { mitos, diarrea. }\end{array}$ \\
\hline Tifus & $\begin{array}{l}\text { Rickettsia } \\
\text { prowazekii }\end{array}$ & 1-3 semanas & $\begin{array}{l}\text { Tos, presión en el pe- } \\
\text { cho, dificultad de respi- } \\
\text { rar, náusea, dolor en los } \\
\text { músculos, y deshidrata- } \\
\text { ción. }\end{array}$ \\
\hline $\begin{array}{l}\text { Encefalitis } \\
\text { víricas por } \\
\text { alfavirus }\end{array}$ & $\begin{array}{l}\text { Encefalitis } \\
\text { primarias }\end{array}$ & 6-10 días & $\begin{array}{l}\text { Dolor de cabeza, fie- } \\
\text { bre, rigidez de cuello, } \\
\text { cambios de concien- } \\
\text { cia, somnolencia, entre } \\
\text { otros. }\end{array}$ \\
\hline Oocistos & $\begin{array}{l}\text { Cryptosporidium } \\
\text { parvum }\end{array}$ & 5-14 días & $\begin{array}{l}\text { Diarrea aguda, acuosa, } \\
\text { nauseas, vómitos, dolor } \\
\text { en el abdomen. }\end{array}$ \\
\hline
\end{tabular}

Fuente: Elaboración propia.

Aunque de todas ellas, únicamente se va a hacer alusión a las más virulentas o las que ya están presentes en programas de armas biológicas o han sido protagonistas de ataques bioterroristas.

\subsection{La salmonelosis}

La salmonelosis humana es una enfermedad infectocontagiosa producida por enterobacterias del género salmonella. No todas las especies, cepas o serotipos reconocidos tienen igual potencial patogénico. Los principales agentes etiológicos corresponden a Salmonella typhi, Salmonella 
paratyphi, Salmonella typhimurium y Salmonella enteritidis. La salmonelosis se trasmite a los humanos de varias maneras: por consumir agua o alimentos contaminados con dicha bacteria, por la falta de higiene en la manipulación de alimentos, al tener contacto directo con las heces de una persona o animal infectado, etc. Cualquier persona puede contraer salmonelosis, pero el grupo de mayor riesgo son los niños y los ancianos, por ello muchas epidemias de salmonelosis se registran en guarderías, colegios, campamentos para niños y asilos de ancianos. También los restaurantes pueden convertirse en importantes fuentes de propagación.

Los alimentos que generalmente pueden contaminarse con salmonela son: las carnes crudas o poco cocidas (carnes de res, cerdo, mariscos y aves, especialmente el pollo), la leche no pasteurizada y sus derivados, los huevos crudos o poco cocidos, los brotes de alfalfa y algunos vegetales. Por lo general, los alimentos contaminados parecen en buen estado, pues no huelen ni saben de manera distinta a la habitual. Otras fuentes de exposición pueden incluir el contacto con mascotas infectadas, como tortugas, pollos, perros y gatos.

Los síntomas de salmonelosis aparecen generalmente en uno a tres días después del contagio. Los más comunes son: diarrea (leve o severa), fiebre, dolor abdominal, dolor de cabeza y algunas veces vómitos. Si no se trata la salmonelosis, pueden aparecer perforaciones intestinales y enterorragias, que pueden causar la muerte.

El historial bioterroristas de esta bacteria se centra en el ataque que la secta de Bhagwan Shree Rajneesh realizó a varios restaurantes del Condado de Wasco en Oregón, como ya se ha aludido en el apartado anterior. El problema de este agente es que no se trasmite por contacto directo, sino por vía oral-fecal, su uso queda restringido a la contaminación de agua y alimentos. A pesar de ser una bacteria de cultivo poco exigente, su utilización con fines terroristas requiere de una vehiculización en la industria alimentaria (García de los Ríos y Jiménez-Gómez, 2007, p. 156). 


\subsection{El cólera}

El cólera es una enfermedad producida por Vidrio cholerae, una bacteria gram-negativa con forma curvada. $\mathrm{Al}$ igual que ocurre con otras muchas enfermedades transmitidas por el agua, el cólera también se asocia con el consumo de alimentos. Por tanto, el cólera se propaga a través de agua y comidas contaminadas, y no suele trasmitirse de persona a persona. Los síntomas de la enfermedad comienzan con una diarrea repentina, indolora y acuosa, además de vómitos. En los casos graves se llega a perder casi un litro de líquido por hora, produciendo una gran disminución de agua y sal que da lugar a una marcada deshidratación con intensa sed, calambres musculares, debilidad y una producción mínima de orina. Así, si no se trata con suficiente rapidez, la persona puede morir de deshidratación, shock o insuficiencia renal.

En la actualidad, el Vibrio cholerae no supone una amenaza bioterroristas especialmente notable en países desarrollados en los que el agua se potabiliza y no existen núcleos abundantes de personas que permanezcan durante periodos prolongados sin ingerir alimentos (García de los Ríos y Jiménez-Gómez, 2007, p. 170). No obstante, se conoce ataques bioterroristas con este agente, como los asesinatos por envenenamiento de los miembros de la Comisión Lytton de la Liga de Naciones, que en 1931 investigó la invasión de Manchuria.

\subsection{La meloidosis}

La meloidosis es una enfermedad causada por la bacteria Burkholderia pseudomallei. Es, principalmente, una enfermedad tropical, típicamente en el suelo o en aguas turbias acumuladas en superficie, desde donde se puede alcanzar las fuentes de agua bruta y también los sistemas de abastecimiento de agua de consumo. Su manifestación clínica más frecuente es la neumonía, que puede ser mortal. Otros posibles síntomas son las úlceras o abscesos cutáneos, abscesos en órganos internos y enfermedades neurológicas atípicas, como la encefalitis del tronco encefálico o la paraplejia aguda. Aunque pueden sufrir melioidosis los adultos y niños sanos, afecta principalmente a personas cuyos mecanismos de defensa contra las infecciones están debilitados por enfermedades subyacentes o cuya salud general es deficiente debido a una nutrición o condiciones de vida deficiente. $\mathrm{Al}$ parecer, la mayoría de las infecciones se producen 
por el contacto de rozaduras o cortes en la piel con agua contaminada. También pueden producirse infecciones por otras vías, en particular por inhalación o ingestión, aunque se desconoce la importancia relativa de estas vías de contagio.

Como arma biológica, la Burkholderia pseudomallei fue empleada como agente biológico en la Primera Guerra Mundial. Existen evidencias que el Ejército alemán desarrolló un programa para la creación de armas biológicas. Estos agentes fueron usados por los alemanes para contaminar ganado vacuno que fue exportado a Rusia. Japón también desarrolló armas biológicas con este agente durante la Segunda Guerra Mundial. La unidad 731 fue la responsable de epidemias con Vidrio cholerae, B. anthracis, Burkholderia pseudomallei, entre otros.

\subsection{La ricina}

La ricina es una de las toxinas más potentes conocidas, la cual se extrae de las semillas del ricino. Pertenece a la familia de proteínas conocidas como proteínas inactivantes de los ribosomas (RIP) que se unen a los ribosomas de las células eucariotas paralizando la síntesis de proteínas, lo que causa su muerte por apoptosis. Puede producirse en forma de polvo, cápsula o aerosol y logra disolverse en agua. Puede ser inhalada o inyectada, pero también ingerida disuelta en los alimentos o en las bebidas. Al entrar en contacto con la piel puede causar irritación o comezón. No existe antídoto contra esta toxina. Los médicos únicamente pueden suministrar asistencia respiratoria, fluidos intravenosos u otros cuidados. Los síntomas que provocan pueden parecerse a una gastroenteritis típica o una enfermedad respiratoria, con vómitos, nauseas, diarrea o dolor abdominal. La cantidad suministrada determina la agresividad de la enfermedad producida.

Por su naturaleza, es un agente biológico que puede emplearse como arma biológica, con materia prima ampliamente disponible, fácil de producir y distribuir. Se obtiene de los desechos sólidos resultantes de la extracción de aceite de las semillas de ricino mediante el uso de utensilios ordinarios de cocina. Es fácil de producir en grandes cantidades a un coste mínimo y tecnología básica. Además, es seis mil veces más mortal que el cianuro. Así, aunque la ricina no es un microorganismo, cumple con las características ideales de un arma biológica, ya que es muy letal, es fácil 
de obtener en grandes cantidades, es fácil de introducir en armas por ser una toxina relativamente termolábil para ser vehiculizada en armamento militar convencional, es dificil de detectar, y genera un gran impacto en la salud pública (García de los Ríos y Jiménez-Gómez, 2007, p. 233).

Uno de los casos más conocidos del uso de la ricina como bioarma es el asesinato en Londres de Georgy Markov, disidente de Bulgaria, en septiembre de 1978. Este fue llevado a un hospital debido a que sufría una molestia misteriosa, que terminó en una gastroenteritis severa y fiebres altas, que le causó la muerte 3 días después. Antes de morir mencionó que un extraño lo había punzado con la punta de una sombrilla mientras cruzaba el puente de Waterloo. Los doctores fueron incapaces de identificar la causa de la muerte hasta que un inmigrante búlgaro en París denunció estar sufriendo los mismos síntomas del hombre de la sombrilla. Esto llevó a realizar una segunda autopsia a Markov y se encontraron los remanentes de una minicápsula con trazas de ricina.

Otro caso se produjo en 1991, cuando los miembros de un grupo extremista que se oponían a los impuestos, el Consejo de los Patriotas de Minnesota (Patriots Council of Minnesota), se les encontró en posesión de $0.7 \mathrm{~g}$ de ricina. Fueron arrestados y sentenciados por la posesión de un veneno letal para uso como arma, por violación a la Ley Antiterrorista de Armas Biológicas de 1989. La ricina fue producida en un laboratorio casero.

Otro, sucedió en febrero de 2004 en EE.UU., cuando apareció un sospechoso polvo blanco en la oficina del líder de la mayoría del Senado, Bill Frist. Aunque nadie resultó afectado por la exposición al veneno, 16 personas tuvieron que ser descontaminadas.

Otro, se presentó el 6 de noviembre de 2003, cuando el Servicio Secreto interceptó un sobre con ricina dirigido a la Casa Blanca. Esta carta contenía una ampolleta de ricina y fue descubierta en una instalación de correos de la Casa Blanca en la Base Bolling de la Fuerza Área en Washington. El paquete provenía de Chattanooga, Tennessee, también iba dirigido a la DOT vía Casa Blanca. Pero este incidente no fue conocido públicamente. Pero el uso de la ricina no se limita al bioterrorismo, sino también se ha empleado en algún momento en los programas biológicos de países como EE.UU., Reino Unido, Francia, Canadá y la URSS. 


\subsubsection{Agentes biológicos de Categoría $C$}

Se trata de patógenos emergentes que pueden ser manipulados para su diseminación masiva, debido a su disponibilidad, facilidad de producción y diseminación, y altas tasas de morbilidad y mortandad, generando un gran impacto en la salud públicas.

Entre los agentes de esta categoría están enfermedades infecciosas emergentes, como:

- El virus Nipah, causa encefalitis transmitida a partir de cerdos, con tasas de mortandad del 18\%.

- Los hantavirus, virus causantes de un síndrome pulmonar relacionado con roedores, con elevadas tasas de mortandad, con el $40-50 \%$.

\subsubsection{Las armas químicas}

Las armas químicas son "aquellas cuya eficacia se debe a la toxicidad de sus principios activos, es decir, su acción química sobre los procesos vitales al ser capaces de causar muerte, la invalidez temporal o el daño permanente" (Organización Mundial de la Salud, 2003, p. 4). Las armas químicas son sustancias que se emplean para provocar bajas en la tropa enemiga por lesión o muerte; minimizar la efectividad del equipo, el armamento y el comando enemigo por contaminación, obligándolo a emplear equipo de protección; reducir la velocidad del enemigo para que sean un blanco más fácil. Ya que un arma química usada contra una población no preparada bajo condiciones climáticas ideales puede ser 500 veces más mortal que una cantidad similar de explosivos convencionales (Villamarín, 2005, p. 186).

En todo caso, estas armas se pueden clasificar de diversas formas, dependiendo de las características por las que se les quiera diferenciar. Por ejemplo, se pueden dividir según su grado de permanencia en la atmósfera: volátiles y persistentes. Los primeros son sustancias que no permanecen mucho tiempo en el área expuesta, sino que se evaporan o dispersan rápidamente y pueden, por tanto, usarse para causar víctimas en un área que va a ocuparse poco tiempo después. Los segundos si- 
guen actuando en el área expuesta durante periodos prolongados. Otra manera de clasificar los agentes químicos es según su vía de entrada en el cuerpo: agentes respiratorios y agentes cutáneos. Los primeros son inhalados y pueden causar daño pulmonar o ser absorbidos y efectos sistemáticos, y los segundos, son absorbidos a través de la piel y la lesionan o entran al organismo y causan efectos sistemáticos, o las dos cosas. Y otra, responde al efecto principal que se pretenda obtener, es decir, hostigamiento, invalidez o muerte. Un agente de hostigamiento incapacita a las personas durante el tiempo de exposición. Un agente de invalidez también incapacita, pero las personas expuestas a él pueden no darse cuenta de su predicamento, y se ven impedidas para realizar determinadas acciones. Y un agente letal causa la muerte de las personas expuestas. Pero también se puede distinguir según sus efectos específicos en el cuerpo y su composición, como a continuación:

1. Agentes nerviosos (tabú, sarín, soman, agentes VX, agentes VE, agentes VG, agentes VS).

2. Agentes sanguíneos (cianuro y organoclorados).

3. Agentes vesicantes (lewisita, sulfato mostaza, etc.).

4. Agentes pulmonares (fosgeno).

5. Agentes lacrimógenos (gas lacrimógeno, $\mathrm{CR}, \mathrm{CR}, \mathrm{CN}$ ).

6. Agentes incapacitantes (BZ).

\subsubsection{Agentes nerviosos}

Los agentes nerviosos son los más tóxicos y los más rápidos de acción entre los agentes bélicos químicos conocidos. La designación de "gas nervioso" se usa para los compuestos organofosforados y otros organofosfados que inhiben la colinesterasa tisular en humanos en pequeñas dosis. Su nombre alude al modo de acción de estas substancias, principalmente la alteración de la trasmisión de los impulsos nerviosos. Sus orígenes se remontan a los años treinta, con la síntesis del sarín y tabun por parte de químicos alemanes, aunque después de la Segunda Guerra Mundial se desarrollaron otros agentes como el somán y los de la serie $\mathrm{V}(\mathrm{VX}, \mathrm{VE}, \mathrm{VG}, \mathrm{VS})$. 


\subsection{El sarín, el tabun y el somán}

Los tres son agentes nerviosos. El sarín, conocido también como GB, es un líquido incoloro e insípido que en su forma pura no tiene olor. Sin embargo, el sarín puede evaporarse formando un vapor/gas y diseminarse en el ambiente. El tabun, también es conocido como GA, es claro y tiene un leve olor a fruta. $\mathrm{Al}$ ser calentado, el tabun líquido rápidamente se convierte en gas. Y el somán, también es conocido como GD, es un líquido claro, incoloro e insípido que tiene un leve olor a alcanfor o fruta podrida, pero al calentarse se convierte en vapor. Como cualquier arma química, para las Naciones Unidas están clasificadas como unas armas de destrucción masiva, según Resolución 687 de la ONU.

En todo caso, las personas pueden quedar expuestas a estas sustancias:

1. En la liberación de las mismas en el aire, las personas pueden quedar expuestas a través del contacto con la piel o con los ojos, y claro está, respirándolo.

2. En el agua, las personas pueden quedar expuestas al comer los alimentos contaminados.

3. En la ropa, una persona puede liberarlo durante unos 30 minutos después de que esta haya entrado en contacto con los vapores de este gas; $y$

4. En la ropa, una persona puede liberar tabun durante aproximadamente 30 minutos después de haber entrado en contacto con el vapor del tabun.

Pero el grado de envenenamiento depende de la cantidad de sarín a la cual una persona ha estado expuesta, a cómo y al período de exposición. Los síntomas aparecerán dentro de un lapso de unos pocos segundos después de la exposición al sarín en forma de vapor y desde unos pocos minutos hasta 18 horas después de la exposición a su forma líquida. Los efectos y consecuencias que tienen para una persona son diversos. Por ejemplo, las personas expuestas a una dosis baja pueden presentar los siguientes síntomas: goteo nasal, ojos lagrimosos, pupilas pequeñas y uniformes, dolor en los ojos, visión borrosa, babeo y sudoración ex- 
cesiva, tos, opresión en el pecho, respiración rápida, confusión, somnolencia, debilidad, náuseas, dolor de cabeza, presión sanguínea alta o baja, entre otras. La exposición a grandes dosis de sarín por cualquier vía ocasionan los siguientes efectos perjudiciales: pérdida de conciencia, convulsiones, parálisis, insuficiencia respiratoria, etc. Y las personas con una exposición severa probablemente no sobrevivirán, y presentarán los siguientes síntomas: tremores y contracciones musculares incontrolables, convulsiones, y la muerte.

Su uso se ha extendido desde la Segunda Guerra Mundial, se presume que se utilizó en la guerra de Irán e Irak en los años ochenta, y en los noventa fue utilizado por la secta religiosa Aum Shinrikyo, en Japón, en los ataques terroristas de 1994 y 1995 y en Washington en el 2001. Existen menciones de su almacenamiento en Australia durante la Segunda Guerra Mundial para evitar una invasión, y también de su producción y almacenamiento en Chile en la denominada "Colonia Dignidad". Una excelente arma química, con tan solo un miligramo de gas sarín se puede matar a una persona.

\subsection{Los agentes de la serie $V$}

Incluyen los agentes VX, VM, VE, VG, VS compuestos similares, pero son más tóxicos y persistentes que los agentes neurotóxicos de serie $\mathrm{G}$, y pueden ser utilizados para contaminar un territorio durante mayor espacio de tiempo. Estos agentes, a diferencia de los de la serie V, actúan primariamente a través de la penetración de la piel y de la inhalación de aerosoles. Ya que a pesar de lo que puede pensar mucha gente, el agente VX, no es un gas nervioso, sino un líquido muy viscoso y pálido que parece aceite de motor. La alta viscosidad del VX hace que sea muy persistente, debido a que es muy difícil quitar del suelo y el agua, y con el tiempo se evapora liberando peligrosos gases. Aunque el VX también puede producirse, como ya se ha dicho, como aerosol.

La exposición a este tipo de agentes provoca la muerte por asfixia, a menos que la víctima reciba un tratamiento médico. Los primeros síntomas son temblores, sudoración, náuseas, dificultad para respirar y una nariz irritada. A medida que el agente se adentra en el cuerpo, interfiere con una enzima en los músculos, haciendo que todos los músculos se 
contraigan. Esto llevará a la obstrucción completa de las vías respiratorias, causando en la víctima la muerte por falta de aire.

Los agentes nerviosos se desarrollaron antes de la Segunda Guerra Mundial en Alemania. Los alemanes disponían de grandes reservas de estos productos pero no los utilizaron durante la guerra, por razones que no están del todo claras. Justo antes de comenzar el conflicto, los aliados descubrieron estos almacenes y fabricaron estos productos, concretamente el GB y VX. Los agentes nerviosos constituyen una de las mayores amenazas militares. Solo se tiene evidencia de su utilización en el conflicto Iraq-Irán. Los servicios de inteligencia indican que muchos países tienen tecnología para la fabricación de estos productos, aunque su producción, almacenamiento y la investigación con estos agentes está prohibida por la Convención sobre Armas Químicas desde 1993.

\subsubsection{Agentes sanguíneos}

Inhiben la entrada de oxígeno a la sangre, causando así la asfixia y la muerte.

\subsection{El cianuro}

El cianuro, también conocido como ácido hidrociánico o HCN, es un agente letal de acción rápida que inhibe la respiración aerobia a nivel celular e impide la utilización del oxígeno por las células. El HCN líquido, que a la presión atmosférica se presenta en un rango de temperaturas entre $-14^{\circ} \mathrm{C} y+26^{\circ} \mathrm{C}$, es incoloro a pardo amarillento en apariencia, y su olor es a almendras amargas o mazapán. En reposo, se polimeriza y puede explotar, aunque se puede estabilizar.

El cianuro de hidrógeno se encuentra disponible ampliamente en la industria química como un producto intermedio. Se usa como plaguici$\mathrm{da}$, rodenticida, fumigante $\mathrm{y}$, en ciertos países donde todavía se practica la pena capital, como instrumento para la muerte por parte del Estado. Una exposición más general al cianuro se presenta a través del humo del tabaco, la inhalación del humo de los incendios y, en el África subsahariana, de los glucósidos de cianuro en el tubérculo de la yuca de cazabe. 
La inhalación es la vía de entrada más probable y causa inicialmente hiperventilación. Los vapores de HCN no atraviesan la piel, pero el HCN líquido penetra la piel, como lo pueden hacer muchos aerosoles. Los síntomas de la intoxicación se inician rápidamente puesto que el gas se absorbe rápidamente desde los pulmones. Primero se presenta una hiperventilación que aumenta con la dosis inhalada. En exposiciones bajas, los síntomas de las personas son: sentirse aprehensivos, disnea, dolor de cabeza, vértigo y sabor metálico en la boca. En concentraciones medias pero todavía letales, las personas pueden presentar los siguientes síntomas: calor, postración, vómitos, probable dolor de cabeza, dificultad de respirar, inconciencia y asfixia. En concentraciones altas, las víctimas notan una sensación de constricción de la garganta, vértigo, confusión y disminución de la visión. Las sienes se sienten apretadas y se puede presentar dolor en la nuca y en el tórax. Le sigue la inconciencia y el individuo se desploma. Si no se retira a la víctima de la atmósfera de HCN se presentará la muerte en 2 a 3 minutos, precedida por breves convulsiones y falla respiratoria.

Este agente ha sido empleado como arma química, por ejemplo, las FARC usaban el cianuro para rellenar con esta sustancia las puntas de la munición, especialmente ahuecadas para tal efecto. De tal manera, que esta munición produce un daño letal a sus víctimas. Esta táctica también está siendo empleada por el ELN. En 1993, una bomba cargada de cianuro explosionó en Nueva York en el World Trade Center. El cianuro también fue utilizado como arma química por los franceses durante la Primera Guerra Mundial. Los alemanes utilizaron el conocido como Zyklon B, que contenía cianuro de hidrógeno, para matar grandes cantidades de personas en sus campos de concentración, como los de Auschwitz y Majdanek, durante el Holocausto. Implicado también en uno de los accidentes químicos más importantes ocurridos hasta la fecha en la década de los ochenta en Bhopal (India), al producirse un escape de metil isocianato, con 5000 muertos y 200.000 afectados.

\subsubsection{Agentes vesicantes}

Los agentes vesicantes son irritantes tisulares. Su principal característica es su capacidad de producir lesiones ampollosas en la piel. Los dos grupos principales de vesicantes son los derivados de la dicloroarsina y 
los así llamados "mostazas". Estos últimos son los más importantes militarmente, puesto que no tienen el efecto irritante inicial de las dicloroarsinas y su olor se detecta menos fácilmente, de tal manera que se ajustan mejor para el ataque insidioso.

\subsection{Lervisite}

El lewisite, también conocido como el 2-clorovinildicloroarsia, es un líquido oleoso inodoro e incoloro, que se congela a $-18^{\circ} \mathrm{C}$ y hierve a $190^{\circ} \mathrm{C}$, y huele a geranios. El lewisite es prácticamente insoluble en agua, pero soluble libremente en solventes orgánicos. Se hidroliza rápidamente cuando se mezcla con agua o se disuelve en soluciones alcalinas acuosas como la solución de hipoclorito de sodio.

La exposición puede presentarse al líquido o al vapor, por inhalación o por contacto con la piel. El lewisite es aproximadamente 7 veces menos persistente que el gas mostaza. El periodo de latencia desde la exposición hasta los síntomas parece ser más corto con lewisite que con el gas mostaza. En exposiciones breves, los síntomas son: irritación ocular, tos, estornudos, lagrimeo y vómitos. En contacto con la piel, hay una sensación de quemadura, y el eritema y las ampollas que le siguen unas pocas horas después son dolorosas. La respiración puede ser difícil, seguida en los casos graves de formación de pseudomembranas y edema pulmonar. La toxicidad hepática y la sistémica por arsénico - diarrea, neuropatía, nefritis, hemólisis, choque y encefalopatía- pueden aparecer después de la contaminación cutánea extensa. Las lesiones oculares pueden ser particularmente serias con posterior ceguera a no ser que la descontaminación sea muy pronta. La ingestión lewisite produce un ardor en la boca y la garganta, fuerte dolor de estómago, náuseas, vómitos y sangre en las heces. Si se respira, la persona inmediatamente sentirá irritación de las vías respiratorias, además puede que sienta dolor de quemaduras en la nariz y en los senos nasales, laringitis, tos, falta de aliento, náuseas y vómitos. También puede sufrir daño en el tejido respiratorio y acumulación de líquido en los pulmones, lo que puede causar la muerte.

Se desarrolló como arma secreta en Nela Park, Ohio y recibió el nombre "nuevo G-34" a fin de que se confundiera su desarrollo como gas mostaza. Es más, es posible que la Lewisita fuera usada como arma quí- 
mica por Japón contra las fuerzas chinas en los años 30, aunque no hay ninguna confirmación oficial ni pública. Tras la Primera Guerra Mundial, EE.UU. mostró un gran interés por este agente, debido a que no era inflamable. Las pruebas de campo hechas con la lewisita durante la Segunda Guerra Mundial demostraron que no se podían alcanzar concentraciones letales en condiciones de alta humedad debido a su elevado nivel de hidrólisis. Además, su olor característico y el elevado lagrimeo obligaban a las tropas a usar máscaras antigás y evitar las zonas contaminadas. Los Estados Unidos produjeron unas 20.000 toneladas de lewisita, que usaron principalmente como anticongelante para el gas mostaza, o para penetrar las ropas de protección en situaciones especiales.

\subsection{Gas mostaza}

El gas mostaza, también conocido como sulfuro bis (2-cloroetil), es un líquido oleoso de incoloro a ámbar, de reacción neutra, que se congela a $14^{\circ} \mathrm{C}$ cuando está puro y hierve a $228^{\circ} \mathrm{C}$ con descomposición lenta. A concentraciones altas, tiene un olor picante que se parece al del rábano, la cebolla o el ajo, mucho del cual se puede deber a contaminación con sulfuro de etilo o productos similares intermedios de su síntesis. Tan solo es ligeramente soluble en agua, pero se puede disolver en solventes orgánicos y en grasas.

La exposición, tanto a la forma líquida como a los vapores se presenta principalmente por inhalación y por contacto con la piel. El gas mostaza produce efectos significativos en un rango amplio de dosis. El viento puede transportar los vapores de gas mostaza a grandes distancias. Se puede presentar la contaminación local con agua expuesta al gas mostaza de azufre, el gas mostaza líquido tiende a hundirse como una capa oleosa pesada en el fondo de los estanques de agua, dejando una película oleosa peligrosa en la superficie.

Los signos y los síntomas usualmente se desarrollan en el siguiente orden. Los primeros síntomas definidos, generalmente, se presentan en los ojos entre 30 minutos y 3 horas después de la exposición, empiezan con una sensación de arenilla, dolor progresivo e inyección conjuntival y progresan a edema, presentando todo el fenómeno de conjuntivitis aguda, con dolor, lagrimeo, blefaroespasmo y fotofobia. Hay aumento de las 
secreciones nasales, estornudos, dolor de garganta, tos y ronquera y se puede desarrollar disnea. De 4 a 16 horas después de la exposición, estos síntomas se tornan mucho más acentuados y molestos: los ojos empiezan a presentar secreciones y son muy dolorosos, la secreción nasal es más purulenta y la voz es ronca o la persona se queda sin voz. Se presentan náuseas, arcadas y vómito asociados con dolores epigástricos en una gran proporción de sujetos y pueden recurrir con intervalos frecuentes por varias horas. En los casos graves, pueden llegar a ser intensos y prolongados. Se puede presentar diarrea, pero es bastante inusual. La piel puede empezar a rascar durante este periodo y los exantemas cutáneos pueden mostrar un eritema oscuro en las partes expuestas del cuerpo y en las axilas y los genitales, con ampollas que comienzan a aparecer. Al final de las primeras 24 horas, todos estos síntomas pueden haberse incrementado en intensidad, pero la muerte casi nunca sucede en el primer día.

Los alemanes utilizaron el "gas mostaza" por primera vez en la Gran Guerra contra soldados canadienses en 1915, y posteriormente, contra los franceses en la Tercera Batalla de Ypres. Los alemanes lo utilizaban, o bien en forma de aerosol (recuerda que no es un gas, sino un líquido) o en el interior de bombas de artillería. Cuando era lanzado contra la infantería, causaba estragos: no porque matase a muchos soldados, pues no lo hacía (recuerda que hace falta un 50\% de exposición de la piel). Incapacitaba a muchos de ellos, produciendo gran sufrimiento y llevando a los servicios médicos del enemigo al borde del colapso. Además, el gas mostaza ha sido utilizado como arma química después de la Primera Guerra Mundial. El Reino Unido lo usó contra el Ejército Rojo en 1919; España contra los rebeldes beréberes en la guerra de Rif, en 1921-1927; Italia contra Libia en 1930, la Unión Soviética en Xinjang contra China en 1934 y 1936-37, Italia contra Abisina en 1935-1940. Durante la Segunda Guerra Mundial, Alemania lo utilizó contra Polonia y la Unión Soviética, Japón contra China en 1937-1945. Después, Egipto lo empleó contra Yemen del Norte en 1963-1967, Irak contra Irán en 1981 y en 1983-88, Irán contra Irak en 1987-1988, Irak contra los kurdos en 1988, y Sudán contra los insurgentes en la guerra civil en 1995 y 1997. Así, todavía el gas mostaza está considerado como el agente químico más peligroso entre los países del antiguo Pacto de Varsovia y los países más pobres. 


\subsubsection{Agentes pulmonares}

Normalmente son gases o líquidos muy volátiles que al inhalarse irritan y dañan severamente los conductos bronquiales y los pulmones. Estos últimos gradualmente se llenan de fluidos de la corriente sanguínea. Esto inhibe el suministro de oxígeno al cuerpo y eventualmente causan la muerte por asfixia. Los principales gases irritantes respiratorios son el gas cloro y el fosgeno.

\subsection{El fosgeno}

El principal gas irritante respiratorio es el fosgeno, también es conocido como dicloruro de carbonilo, es un gas incoloro a temperatura ambiente, pero es un líquido humeante por debajo de $8,{ }^{\circ} \mathrm{C}$, y se vuelve líquido fácilmente bajo presión. Se preparó por vez primera en 1812 y es ampliamente utilizado en la industria química como un producto intermedio en la manufactura de tinturas, plaguicidas, productos farmacéuticos, polímeros, resinas y endurecedores, entre otros. Aunque también se produce durante la descomposición térmica o foto-oxidación de los solventes clorados y cuando se quema cloruro de polivinilo (PVC).

Aunque es un gas, se transporta en forma líquida en unos contenedores que, al explosionar, lo vaporizaban, formando una nube blanca que de forma espontánea se convertía en un gas más denso que el aire, incoloro pero con olor a heno enmohecido.

Los efectos que ocasiona, depende del grado de exposición de la persona. Por ejemplo, si la misma no excede de 3 minutos, los síntomas que puede presentar la persona son la irritación de los ojos, la nariz y la garganta. Si estos son los únicos síntomas, desaparecerán rápidamente después de que cese la exposición. Pero si se excede de 30 minutos, los síntomas serán los anteriormente mencionados, hay que añadirles los síntomas respiratorios. Con la exposición a dosis grandes, los síntomas se incrementan y se transforman en un edema pulmonar, que algunas veces puede ser fatal.

El fosgeno es un producto irritante respiratorio, veinte veces más potente que el gas cloro. Fue utilizado por Francia durante la Primera Guerra Mundial, bajo la dirección del químico francés Víctor Grignard 
en 1915. Los alemanes también lo utilizaron contra las tropas británicas en Nieltje, cerca de Ypres, Bélgica, el 19 de diciembre de 1915. En este ataque se liberaron 88 toneladas de gas envasado en cilindros, causando 1069 bajas y 120 muertes. Supuestamente el régimen de Sadam Hussein también lo empleo en 1987 en la guerra entre Irak e Irán.

\subsection{El cloro}

El cloro existe como un gas amarillo-verdoso a temperaturas y presiones ordinarias. El cloro entra en el cuerpo al ser respirado el aire contaminado o al ser consumido con comida o agua contaminadas, aunque no permanece en el cuerpo, debido a su reactividad. Los efectos del cloro en la salud humana dependen de la cantidad de cloro presente, y del tiempo y la frecuencia de exposición. Los efectos también dependen de la salud de la persona y de las condiciones del medio cuando la exposición tuvo lugar. La respiración de pequeñas cantidades de cloro durante cortos periodos de tiempo afecta negativamente al sistema respiratorio humano. Los efectos van desde tos y dolor pectoral hasta retención de agua en los pulmones. El cloro irrita la piel, los ojos y el sistema respiratorio. Además, el cloro irrita las mucosas e hiperreactividad bronquial en individuos susceptibles.

El cloro fue desarrollado y utilizado por Alemania durante la Primera Guerra Mundial, fue el primer producto químico letal. En la primavera de 1915, los ataques masivos sorpresa con este gas causaron miles de víctimas, ya que en un principio los respiradores usados para proteger las tropas eran imperfectos. Téngase en cuenta que el cloro puede reaccionar con el agua en la mucosa de los pulmones para formar ácido clorhídrico, un irritante que puede ser letal, y solo se puede evitar con una máscara de gas apropiada. Además, el 22 de abril de 1915, el ejército alemán tenía 160 toneladas de cloro repartidas en 5.730 cilindros frente al Langermarck, al norte de Ypres (Bélgica). Los alemanes liberaron el gas, formándose una nube que se desplazó hasta las posiciones de las tropas francesas, las que abandonaron sus trincheras creando una franja vacía de $7 \mathrm{~km}$ entre las líneas aliadas. Pero los alemanes también emplearon el gas en tres ocasiones más, el 24 de abril contra la Primera División de Infantería de Canadá, el 2 de mayo cerca de Mouse Trap 
Farm y el 5 de mayo contra los británicos en la Colonia 60. El gas del cloro también ha sido usado por insurgentes contra la población local y las fuerzas de coalición en la Guerra de Iraq, en la forma de bombas de cloro. Por ejemplo, el 17 de marzo de 2007, se produjeron tres artefactos cargados con cloro y fueron detonados en la provincia de Ámbar, matando a dos personas e infectando a 350 .

\subsubsection{Agentes lacrimógenos}

Irritantes sensoriales que causan un lagrimeo temporal, irritación de la piel y de las vías respiratorias y ocasionalmente náuseas y vómito. Son utilizados principalmente para represión de disturbios, pero también han sido usados durante la guerra.

El Gas CS es el nombre común para clorobenzilideno malononitrilo, es un sólido blanco, cristalino a temperatura ambiente. Es un lacrimógeno que se desarrolló inicialmente para reemplazar el CN para uso de la policía, pero que posteriormente fue ampliamente utilizado en el campo de batalla. De acción más rápida que el CN, es intensamente irritante para los ojos y las membranas mucosas de la nariz y el tracto respiratorio superior. También es un irritante general de la piel. Para uso de la policía, se puede diseminar como un aerosol generado pirotécnicamente, como una nube de polvo o, en solución, como un aerosol líquido.

Los síntomas que presentan las personas expuestas a este agente son: ardor, sensación de quemadura en los ojos, lagrimeo, rinorrea, salivación, blefaroespasmo, inyección de la conjuntiva, estornudos y tos que se desarrollan rápidamente a concentraciones de hostigamiento. El tórax se puede sentir adolorido y apretado y algunos individuos pueden aguantar la respiración voluntariamente. La piel expuesta, en particular en las áreas húmedas, comienza a arder y a sentirse quemada después de unos pocos minutos, y le sigue el eritema. Algunos individuos pueden sentir náuseas y vómitos. Cuando se disemina el CS en un solvente transportador, la exposición a este último puede, en ocasiones, complicar aún más el cuadro clínico. Es posible que se deposite más CS en la piel y en los ojos con este procedimiento y tanto la irritación de los ojos como de la piel serán más persistentes. 
El gas CN o cloroacetofenona es un sólido cristalino blanco que se funde a $59^{\circ} \mathrm{C}$ y tiene una presión de vapor considerable. Es un lacrimógeno que estuvo en desarrollo a finales de la Primera Guerra Mundial, y poco tiempo después era usado ampliamente por las fuerzas de policía. Es intensamente irritante para los ojos y las membranas mucosas de la nariz y el tracto respiratorio superior. La policía lo disemina como un aerosol generado pirotécnicamente, como una nube de polvo o, en solución, como un rociado líquido, sobre todo en la represión de disturbios.

Se presenta irritación de la nariz y del tracto respiratorio después de la inhalación e irritación de la piel después del contacto directo. Los síntomas se presentan casi instantáneamente: ardor, sensación de quemadura, abundantes lágrimas, salivación y rinorrea excesivas, opresión torácica, irritación de ojos, disnea y sensación de ahogo.

El CR, también conocido como dibenzo-(b, f)-1:4-oxazepina, es un irritante sensorial sólido amarillo pálido que es unas seis veces más poderoso que el CS. Es intensamente irritante para los ojos y las membranas mucosas de la nariz y el tracto respiratorio superior. Su aplicación en solución líquida produce irritación intensa de la piel, pero los efectos son menos persistentes que los producidos por el CS o el CN. Se puede diseminar como un aerosol generado pirotécnicamente o como un rociado líquido.

Los síntomas se presentan rápidamente: ardor y quemadura de los ojos, lagrimeo, blefaroespasmo, inyección de la conjuntiva, rinorrea, salivación, estornudos, tos, dificultad para abrir los párpados y respirar, sabor desagradable, presión sanguínea, irritación, entre otros. Además, las personas que han sufrido una exposición de más de 30 minutos se pueden quejar de una sensación de "arenilla" en los ojos y de una quemadura leve en la piel. No obstante, los efectos principales del CR en los ojos y la piel probablemente duren menos de 30 minutos, pero el enrojecimiento de los ojos puede persistir varias horas. El dolor y el eritema de la piel se presentan a los pocos minutos de la contaminación. Aunque el dolor disminuye generalmente dentro de los 30 minutos siguientes, ocasionalmente se vuelve a presentar cada vez que se lava la piel. Es probable que la incomodidad torácica y de la respiración se normalice 
en 15 a 30 minutos, como con el CS. Los efectos del CR en los ojos son usualmente inmediatos pero transitorios, causa lagrimeo menor e irritación de la conjuntiva por 1 hora.

Los primeros usos de gases lacrimógenos como arma química se utilizaron en la Primera Guerra Mundial. Los franceses emplearon granadas rellenas de este gas contra los alemanes en agosto de 1914. Pero Alemania respondió con la misma moneda en octubre de 1914, cuando dispararon obuses de fragmentación rellenos de este tipo de gases contra las posiciones francesas en Neuve Chapelle, aunque la concentración fue tan pequeña que apenas se percibió. En la guerra de Vietnam también usaron este tipo de gas, en concreto el CN, el CS y el DM.

\subsubsection{Agentes incapacitantes}

Durante la mayor parte del siglo pasado, los productos químicos incapacitantes han sido utilizados ampliamente, por ejemplo, por la policía y otras fuerzas con el fin de hacer cumplir las leyes; por veterinarios para capturar animales peligrosos; por médicos para sedar o calmar pacientes; por ladrones y otros criminales para incapacitar a sus víctimas y por las fuerzas militares para alcanzar objetivos tácticos con una disminución de la pérdida de vidas. Ya que estas substancias provocan efectos que neutralizan al combatiente a pelear, pero en dosis habituales no deben causarle la muerte.

En relación con las aplicaciones militares, las autoridades de defensa diferencian tres clases de químicos incapacitantes. Clase A: agentes que causan invalidez física temporal como sueño, parálisis temporal, debilidad, ceguera temporal o serias alteraciones respiratorias y que no implican peligro de muerte o de invalidez permanente. Clase B: agentes que en pequeñas dosis causan invalidez física temporal, pero que en grandes dosis pueden causar la muerte o efectos permanentes. Clase $C$ : agentes que causan incapacidad mental.

Una clase potencial de agentes incapacitantes son las potentes drogas psicotrópicas. Estas afectan el sistema nervioso central de diversas formas, de tal manera que el comportamiento de los individuos expuestos se altera y los incapacitan para realizar acciones militares. Aunque, 
una droga de este tipo no siempre causa cambios en el comportamiento, especialmente si hay otras personas que no la reciben. Con el LSD, por ejemplo, se ha demostrado que los soldados drogados pueden comportarse de manera aparentemente normal si están en una unidad con otros que no se encuentran bajo la influencia de la droga. No obstante, los productos psicoquímicos pueden causar incapacidad física y presentar los siguientes síntomas: visión borrosa, desmayos, vómito y falta de coordinación.

El agente más importante es el BZ, también conocido como sal hidrocloruro del 3 quinuclidinil benzilato, es un sólido soluble en agua que se funde a $239-241^{\circ} \mathrm{C}$. Su base libre es un sólido que se funde a $164-167^{\circ} \mathrm{C}$. Algunas veces considerado como un producto psicoquímico, el BZ es un compuesto anticolinérgico similar a la atropina. Se puede diseminar en forma de aerosol de las soluciones, por pirotecnia o como un polvo de tamaño preestablecido. La inhalación es la vía más probable, pero el BZ también es activo por las vías intravenosa, intramuscular y oral.

El inicio de los síntomas es bastante rápido, sin importar la vía de administración. Los signos y los síntomas de exposición incluyen aumento de la frecuencia cardiaca y de la presión sanguínea, piel y boca seca, midriasis, visión borrosa, ataxia, y desorientación y confusión que llevan a estupor. Con exposiciones más bajas, los sujetos pueden ser apreciablemente más lentos en el accionar, menos alertas y somnolientos. A medida que aumentan las dosis, los síntomas se intensifican y se deteriora la coordinación motora, aumentan la confusión, la aprehensión y la inquietud y los sujetos pierden contacto con la realidad y caen en estupor.

En el año 184 a.C., Aníbal usó plantas de belladona para desorientar a las tropas enemigas, y el obispo de Muenster intentó asaltar la ciudad de Groningen con granadas que contenían esta planta. En 1881 miembros de una expedición en el Norte de África observaron que algunas tribus utilizaban deliberadamente Hyoscyamus falezlez. En 1908, soldados franceses en Hanoi fueron intoxicados con plantas de estas características. Se ha acusado a la Unión Soviética de utilizar internamente estos compuestos. En 1998 existen alegaciones del uso de estos productos por parte del Ejército yugoslavo frente a los refugiados de Bosnia, para causar un estado alucinatorio y comportamiento irracional. 


\subsection{Seguridad biológica}

La Organización Mundial de la Salud (OMS) define más acertadamente la situación actual de riesgo en este ámbito cuando afirma que

las amenazas derivadas de este ámbito se han visto incrementadas últimamente en todo el mundo, en parte debido a la rápida evolución de áreas tales como la ingeniería genética, la microbiología y la biotecnología, pero también debido a la facilidad de acceso a las mismas (Soteras, 2007, p. 14).

Como se puede comprobar, los riesgos biológicos son muy actuales, debido en parte a la propia globalización, pero hay que señalar que las crisis de carácter biológico cuentan con una dilatada existencia a través de la historia, a lo largo de la cual, y de forma genérica, se puede llegar a afirmar que estas se han manifestado de dos formas diferentes: las producidas de forma involuntaria (originadas por lo que denominamos "riesgos") y las producidas de forma voluntaria (originadas por lo que denominamos "amenazas") (Soteras, 2007, p. 14). Las primeras están ocasionadas por accidentes en laboratorios y hospitales, tanques de transportes, higiene industrial, entre otros, mientras que las segundas vienen producidas por las bioarmas que pueden ser usadas en guerras rápidas o de desgaste, atacando a seres humanos o a vegetales y animales (para destruir fuentes de abastecimiento), o simplemente para crear terror en la población civil o militar (bioterrorismo), afectando a la capacidad de combate y productiva del adversario y quebrando su voluntad de lucha (Martín Otero, 2011, p. 1).

Así, se podría decir, que la mejor defensa ante un incidente con agentes biológicos consiste en evitar la exposición, lo que implica la necesidad, al menos, de una detección cercana al tiempo real de los niveles de agentes durante el ataque y la provisión de esa información al mando y control, de forma que disponga de una base que le permita predecir una reducción del peligro y gestionar una respuesta a la crisis. Por tanto, la prevención juega un papel fundamental en la seguridad biológica y química, de ahí que sea crucial invertir en investigación y desarrollo para perfeccionar las técnicas y, sobre todo, las herramientas que permitan avanzar en la detección de todos los riesgos y las amenazas. Es más, según la Organización Mundial de la Salud (OMS), 
todos deberían ser capaces de detectarlos, comprobar rápidamente y responder de forma adecuada a las amenazas de enfermedades emergentes y con tendencia a producir epidemias, a fin de reducir al mínimo su impacto en la salud y la economía de la población mundial (Soteras, 2008b, p. 157).

Tal es así, que ella decide crear el Sistema de Alerta y Respuestas de Epidemias y Pandemeias (EPR) y la Red Mundial de Alerta y Respuesta ante Brotes Epidémicos (GOARN), con el propósito de ser unas herramientas de coordinación global y de apoyo a la propia gestión nacional de riesgos y amenazas. En este mismo sentido, la Unión Europea creó la Red de Vigilancia Epidemiológica y Control de las Enfermedades Transmisibles y el Sistema de Alerta Rápida (RAS).

También a nivel internacional, nació en 1985, el Grupo Australia con la participación de 15 Estados y su objetivo inicial era evitar el comercio de los materiales necesarios para la fabricación de armamento químico. Así pues, el objetivo principal del Grupo Australia es el de garantizar, mediante medidas reguladoras de la exportación de determinadas sustancias químicas, agentes biológicos y elementos y equipos para la fabricación de sustancias químicas y biológicas de doble uso, que las exportaciones de dichos productos realizadas desde sus países no contribuyan a la proliferación de armas químicas y biológicas. El Grupo persigue este objetivo recurriendo a mecanismos de consulta y armonización que ayuden a maximizar la eficacia de las medidas reguladoras nacionales aplicadas por los participantes. En la actualidad cuenta con 38 miembros (y la Comisión Europea), y todos ellos, no contraen obligaciones jurídicamente vinculantes: la eficacia de la cooperación entre sus participantes depende únicamente de su compromiso con los objetivos de no proliferación de armas químicas y biológicas y de la efectividad de las medidas que cada uno de ellos adopte a nivel nacional. Adicionalmente, elaboran listados comunes de control, entre los que destacan por su importancia, aquellos dedicados a los equipos biológicos de doble uso y los referidos a los agentes biológicos. Por otro lado, establecen directrices sobre la transferencia de artículos biológicos o químicos sensibles que ayudan a crear unas prácticas de conducta responsables en el ámbito de las exportaciones internacionales de estos materiales. Además, pueden establecer medidas de seguimiento y control de las exportaciones. 
Otra propuesta, fue la creación de la Iniciativa de Seguridad frente a la Proliferación (PSI), que buscaba coordinar las acciones internacionales para abordar y confiscar materiales relacionados con armas NBQ destinados a países proliferadores (Pita, 2008, p. 291). Inicialmente esta iniciativa contó con el respaldo de once países (Alemania, Australia, EE.UU., España, Francia, Holanda, Italia, Japón, Polonia, Portugal y el Reino Unido) y se dedicó a operaciones de interceptación marítima, aunque posteriormente se extendería a las aeronaves y los vehículos terrestres. En septiembre de 2003, los países participantes en la PSI aprobaron la Declaración de Principios de Interceptación. Estos se identificaban con las medidas específicas que los países participantes pueden adoptar para interceptar efectivamente el tráfico relacionado con las ADM e impedir la proliferación. Con el tiempo, otros 60 países se han limitado a expresar su apoyo a la PSI, mientras que otros se han manifestado claramente en contra de esta iniciativa (Cánovas, 2011, p. 211). Dos países tan significativos, política y estratégicamente, como China y Rusia cuestionan su legalidad y advierten de sus posibles consecuencias (Cánovas, 2011, p. 211).

Asimismo, existe una actividad indirecta de la ONU sobre la base de la Resolución del Consejo de Seguridad, 1373 de 28 de septiembre de 2001. La resolución pide a los Estados que se adhieran a los instrumentos legislativos universales que están en relación con la prevención y la supresión del terrorismo internacional (Ibáñez, 2005, p. 57). Aunque ninguno de estos instrumentos atañe directamente al bioterrorismo, muchos están relacionados con ello, pues las armas biológicas son un posible medio de acción, pero la raíz del problema es el terrorismo en sí (por ejemplo, las medidas sobre la financiación de grupos terroristas previenen contra ataques bioterroristas masivos) (Ibáñez, 2005, p. 57). Existen doce instrumentos internacionales y un decimotercero sobre Terrorismo Nuclear que fue adoptado por la Asamblea General el 13 de abril de 2005, y que se abrió al público para firmar el 15 de septiembre de este año con motivo de la Cumbre de Jefes de Estado y de Gobierno que conmemora el $60^{\circ}$ aniversario de la ONU (Ibáñez, 2005, p. 57). Esta resolución creó el Counter-Terrorism Committee (CTG) que estaba compuesto por los 15 miembros del Consejo de Seguridad para ayudar a los Estados a que cumplieran la Resolución 1373; el CTC ayuda a 
aumentar la capacidad de los Estados para luchar contra el terrorismo y recomienda cómo debe efectuarse la labor reformadora de la legislación nacional sobre terrorismo, con la finalidad de que la sociedad internacional tienda a tener medidas legales más o menos homogéneas en la lucha contra esta lacra, haciendo de ellas, por tanto, instrumentos más efectivos (Ibáñez, 2005, p. 58).

Ya con anterioridad, se había constituido en 1972, la Convención sobre la Prohibición del Desarrollo, la Producción y el Almacenamiento de Armas Bacteriológicas y Toxinas. En dicha convención se prohibió el desarrollo, producción, almacenamiento, adquisición, conservación y transferencia de armas biológicas y químicas con fines ofensivos, a la vez que obligaba a los Estados miembros que las posean. Y la Convención sobre la Prohibición de Armas Químicas, que distingue tres tipos de sustancias controladas, que bien pueden ser bien usadas como armas en sí mismas o usados en la elaboración de armas. La clasificación se basa en las cantidades de la sustancia producida comercialmente para propósitos legítimos. Cada clase está separada en una Parte A, que son químicos que pueden ser usados directamente como armas, y en una Parte B, que son químicos que pueden ser utilizados en la manufactura de armas químicas. El tratado también se ocupa de los componentes carbónicos denominados "Químicos orgánicos discretos"..Estos son cualquier componente carbónico, además de los polímeros de larga cadena, óxidos, sulfidos y carbonatos metálicos, tales como los organofosforados.

En 2008 se institucionalizó el Equipo Especial sobre la Ejecución de la Lucha contra el Terrorismo, en la Secretaría General, se creó un grupo de trabajo sobre la prevención de los ataques con armas de destrucción en masa. En el marco de su plan de trabajo del año 2009 y de su tarea principal, el grupo de trabajo seleccionó un área específica para su desarrollo: la evaluación de cómo podrían responder el sistema de Naciones Unidas y las organizaciones internacionales, de forma conjunta, a un ataque terrorista en el que se utilizasen armas NBQ-R, y el grado de coordinación previsto entre las distintas entidades para suministrar rápidamente ayuda al o a los Estados afectados (González, 2011, p. 138). Para cumplir este objetivo, se tiene previsto facilitar un intercambio interactivo de conocimientos, así como conocer mejor y compartir informa- 
ción sobre las actividades y planes de emergencia, ya diseñados por las organizaciones internacionales y las entidades relevantes de Naciones Unidas como respuesta, y para mitigar las consecuencias de un ataque con ese tipo de armas de destrucción en masa o materiales afines (González, 2011, p. 138).

La OTAN se ha convertido en una pieza clave en el ámbito militar, ya que está contribuyendo al análisis de las amenazas bioterroristas. Por ejemplo, ha puesto en marcha un Plan Civil de Emergencia para hacer frente a las amenazas del bioterrorismo, iniciativa que se enmarca bajo el paraguas de la activación del art. 5 del Tratado relativo a la defensa mutua de los aliados en caso de ataque. La Interpol también dispone de una unidad de prevención del bioterrorismo en Lyon. Esta trabaja en contacto con cada Oficina Central Nacional de Interpol para asegurar que los fallos sean detectados. Otra iniciativa protagonizada por este organismo es la creación de una Guía de Preparación y Respuesta a un Incidente de Bioterrorismo, que proporciona procedimientos completos, comprehensivos paso a paso para asistir al servicio policial en su preparación para incidentes relacionados con bioterrorismo; y un Centro de Recursos Preventivos en Bioterrorismo, que proporciona materiales de formación, documentos científicos, planes y pautas de dirección de crisis y otra información indispensable (www.interpol.int).

También hay que destacar el Antiterrorism Assistance Program (ATA), que es un programa que ha formado a 48.000 participantes de 141 países desde 1983 (Ibáñez, 2005, p. 59). La mayoría de los beneficiarios de este programa son países desarrollados que carecen de los recursos humanos y otros recursos necesarios para mantener un programa eficaz contra el terrorismo y la infraestructura. La formación se centra en abordar las deficiencias observadas en la capacidad para realizar las siguientes áreas: protección de fronteras nacionales, infraestructuras críticas y liderazgo nacional, responder y resolver los incidentes terroristas, y manejo de incidentes terroristas con implicación a nivel nacional. Además, proporciona asistencia legal y formación en medidas antiterroristas a "naciones amigas" (Ibáñez, 2005, p. 59). Y por último, cabe destacar el importante papel que están desempeñando en los últimos tiempos actores no estatales de la sociedad internacional (Ibáñez, 2005, p. 60). Así, 
por ejemplo, se encuentra el BioWeapons Prevention Project (BWPP), que es una red global de agentes de la sociedad civil dedicada a la eliminación permanente de las armas biológicas y químicas.

Pero también hay que destacar las políticas relacionadas con riesgos y amenazas químicas y biológicas, dado que los países necesitan prepararse para detectar y responder a este tipo de incidentes. Para ello, es vital aprobar medidas que estén dirigidas, por ejemplo, a acrecentar inmediatamente el sistema de salud pública, diseñar y poner en práctica una amplia red de vigilancia de los brotes de enfermedades, conectar con Internet a todos los que proveen servicios de salud y crear recursos en conexión directa que sirvan de depósito central de la información patológica, mejorar la capacidad de los laboratorios de manera que muchos más de estos puedan identificar agentes patógenos, educar e informar a todos los que prestan los servicios de atención médica y a los ciudadanos en general, incrementar los controles, impulsar legislación adecuada para este tipo de infracciones, adquisición de equipos apropiados, establecimiento de protocolos, políticas informativas (tabla 3).

Tabla 3. Acciones básicas para cubrir los aspectos de cooperación y coordinación necesarios para una gestión eficaz de las crisis y emergencias biológicas

\section{OPGIONES PREVENTIVAS}

Prevención/Interferencia

Medidas de bioprotección (buen adiestramiento de laboratorio, buen adiestramiento de fabricación, etc.).

Medidas de seguridad física (instalaciones seguras, cámaras de vigilancia, etc.).

Reorientación de los antiguos científicos de armamento.

Control, verificación de entorno y registro del personal, patógenos e investigación en el interior de la organización al igual que de las rutinas administrativas.

\section{MEDIDAS DE RESPUESTA}

Preparación/Respuesta

Sistemas de alerta temprana y respuesta para limitar el daño y controlar la situación.

Sistemas de vigilancia, coordinados y eficientes (dentro y fuera del territorio nacional).

Sistemas de protección civil (preparación y respuesta).

Mecanismos de coordinación rápidos y oportunos (canales libres para la comunicación vía fax, correo electrónico, teléfono, entre otros). 
Control y verificación del entorno de Directrices para facilitar a los médicos los colegas en otros países y visitas de clínicos la rápida identificación de los investigadores, al igual que de las ruti- agentes que pudieran ser utilizados en nas administrativas.

bioterrorismo u otra amenaza biológica.

Futuros informes sobre científicos e investigadores actuales, en cuanto a las implicaciones potenciales de seguridad de sus productos e investigaciones.

Educar al personal en directrices y estándares de seguridad.

Preparación y planes de contingencia, incluyendo la valoración de riesgos.

Licencia requerida para la transferencia de ciertos patógenos (control de exportación de productos y material de doble uso).

Desarrollar las mejores herramientas para que las aduanas y los oficiales de licencias de mercancías puedan detectar tráfico ilícito de materiales prohibidos.

Expedir certificados de manejo para cierto tipo de patógenos tanto para individuos como para entidades.

Desarrollo de una reserva suficiente de vacunas y fármacos.

Desarrollo de las capacidades diagnósticas para identificar y verificar agentes a través de laboratorios de referencia.

Información a los elementos de primera intervención de los posibles riesgos y amenazas a los que se pueden enfrentar y de cómo informar de ello.

Desarrollo apropiado del equipo de detección y de descontaminación.

Desarrollo de un protocolo de actua-

Seguridad en el transporte. ción para los elementos de primera intervención.

Criminalizar infracción de certificados Identificación de los laboratorios de y acuerdos de licencia y hacer cumplir las condenas.

referencia para gestionar las muestras medioambientales.

Cooperación policial dentro del Estado, y cooperación en seguridad e inteligencia con las industrias y las compañías.

Elaborar un modelo de informe técnico para apoyar la consecuente toma de decisiones para la autoridad competente.

Fuente: (Villamarín, 2005, p. 59). 